medRxiv preprint doi: https://doi.org/10.1101/2021.04.17.21255471; this version posted April 20, 2021. The copyright holder for this preprint (which was not certified by peer review) is the author/funder, who has granted medRxiv a license to display the preprint in perpetuity. All rights reserved. No reuse allowed without permission.

\title{
1 Random glucose GWAS in 493,036 individuals provides insights into diabetes
}

\section{2 pathophysiology, complications and treatment stratification}

3

\section{Authorship:}

5 Vasiliki Lagou ${ }^{1-3^{*}}$, Longda Jiang ${ }^{4-5^{*}}$, Anna Ulrich $^{5^{*}}$, Liudmila Zudina ${ }^{5}$, Karla Sofia Gutiérrez González ${ }^{6-7}$,

6 Zhanna Balkhiyarova ${ }^{5,8-10}$, Alessia Faggian ${ }^{5,8}$, Shiqian Chen $^{11}$, Petar Todorov ${ }^{12}$, Sodbo Sharapov ${ }^{13}$,

7 Alessia David ${ }^{14}$, Letizia Marullo ${ }^{15}$, Reedik Mägi ${ }^{16}$, Roxana-Maria Rujan ${ }^{17}$, Emma Ahlqvist $^{18}$, Gudmar

8 Thorleifsson ${ }^{19}$, He Gao ${ }^{20}$, Evangelos Evangelou ${ }^{20-21}$, Beben Benyamin ${ }^{22-24}$, Robert Scott ${ }^{25}$, Aaron

9 Isaacs ${ }^{6,26-27}$, Jing Hua Zhao ${ }^{28}$, Sara M Willems ${ }^{6}$, Toby Johnson ${ }^{29}$, Christian Gieger ${ }^{30-32}$, Harald Grallert ${ }^{30,32}$,

10 Christa Meisinger ${ }^{33}$, Martina Müller-Nurasyid ${ }^{34-37}$, Rona J Strawbridge ${ }^{38-41}$, Anuj Goel ${ }^{42-43}$, Denis

11 Rybin $^{44}$, Eva Albrecht ${ }^{36}$, Anne U Jackson ${ }^{45}$, Heather M Stringham ${ }^{45}$, Ivan R Corrêa, Jr. ${ }^{46}$, Farber-Eber

Eric $^{47}$, Valgerdur Steinthorsdottir ${ }^{19}$, André G Uitterlinden ${ }^{48-49}$, Patricia B Munroe ${ }^{29,50}$, Morris J Brown $^{29}$,

Schmidberger Julian ${ }^{51}$, Oddgeir Holmen ${ }^{52}$, Barbara Thorand ${ }^{31-32}$, Kristian Hveem ${ }^{52}$, Tom Wilsgaard ${ }^{53-54}$,

Karen L Mohlke ${ }^{55}$, Wolfgang Kratzer $^{51}$, Haenle Mark ${ }^{51}$, Wolfgang Koenig ${ }^{56-58}$, Bernhard O Boehm ${ }^{59}$,

Tricia M Tan ${ }^{11}$, Alejandra Tomas ${ }^{60}$, Victoria Salem ${ }^{61}$, Inês Barroso ${ }^{62}$, Jaakko Tuomilehto ${ }^{63-65}$, Michael

Boehnke $^{45}$, Jose C Florez ${ }^{66-68}$, Anders Hamsten ${ }^{38-39}$, Hugh Watkins ${ }^{42-43}$, Inger Njølstad ${ }^{53-54}$, H-Erich

Wichmann ${ }^{31}$, Mark J Caulfield ${ }^{29,50}$, Kay-Tee Khaw ${ }^{69}$, Cornelia van Duijn ${ }^{6,70-71}$, Albert Hofman ${ }^{48,72}$,

Nicholas J Wareham ${ }^{25}$, Claudia Langenberg ${ }^{25}$, John B Whitfield ${ }^{73}$, Nicholas G Martin ${ }^{73}$, Grant Montgomery ${ }^{73-74}$, Chiara Scapoli ${ }^{75}$, Ioanna Tzoulaki ${ }^{20-21}$, Paul Elliott ${ }^{20,76-77}$, Unnur Thorsteinsdottir ${ }^{19,78}$,

Kari Stefansson ${ }^{19,78}$, Evan L Brittain ${ }^{79}$, Mark I McCarthy ${ }^{1,80-81 \wedge}$, Philippe Froguel ${ }^{5,82}$, Patrick M Sexton ${ }^{83-}$ Ayse Demirkan ${ }^{8,87}$, Tune H Pers ${ }^{12}$, Christopher A Reynolds ${ }^{17,88}$, Yurii S Aulchenko ${ }^{6,89-90}$, Marika A Insulin-related Traits Consortium (MAGIC). 
medRxiv preprint doi: https://doi.org/10.1101/2021.04.17.21255471; this version posted April 20, 2021. The copyright holder for this preprint (which was not certified by peer review) is the author/funder, who has granted medRxiv a license to display the preprint in perpetuity. All rights reserved. No reuse allowed without permission.

^ Current address: Genentech, 1 DNA Way, South San Francisco, CA 94080.

\# These authors jointly directed this research.

Affiliations:

1)Wellcome Centre for Human genetics, University of Oxford, Oxford, United Kingdom; 2)Human

Genetics, Wellcome Sanger Institute, Hinxton, Cambridgeshire, UK; 3)VIB-KU Leuven Center for Brain and Disease Research, Leuven, Belgium; 4)Institute for Molecular Bioscience, The University of Reproduction, Imperial College London, London, UK; 6)Genetic Epidemiology Unit, Department of and Experimental Medicine, School of Biosciences and Medicine, University of Surrey, Guildford, UK;

College London, London, UK; 12)Novo Nordisk Foundation Center for Basic Metabolic Research, and System Biology, Department of Life Sciences, Imperial College London, London, UK; 15)Department of Evolutionary Biology, Genetic Section, University of Ferrara, Ferrara, Italy; 16)Estonian Genome Center, Institute of Genomics, University of Tartu, Tartu, Estonia; 17)Centre for Sport, Exercise and Life Sciences, Faculty of Health and Life Sciences, Coventry University, Alison Gingell Building, UK; 18)Lund University Diabetes Centre, Department of Clinical Sciences Malmö, Lund University, Malmö, Sweden; 19)deCODE genetics/Amgen, Inc., Reykjavik, Iceland; 
medRxiv preprint doi: https://doi.org/10.1101/2021.04.17.21255471; this version posted April 20, 2021. The copyright holder for this preprint (which was not certified by peer review) is the author/funder, who has granted medRxiv a license to display the preprint in perpetuity. All rights reserved. No reuse allowed without permission.

53

54

55

56

57

58

Ioannina, Greece; 22)Australian Centre for Precision Health, University of South Australia, Adelaide,

Australia; 23)Allied Health and Human Performance, University of South Australia, Adelaide,

Australia; 24)South Australian Health and Medical Research Institute, Adelaide, South Australia, Australia; 25)MRC Epidemiology Unit, Institute of Metabolic Science, University of Cambridge, Cambridge, UK; 26)CARIM School for Cardiovascular Diseases and Maastricht Centre for Systems Biology (MaCSBio), Maastricht University, Maastricht, the Netherlands; 27)Department of Physiology, Maastricht University, Maastricht, the Netherlands; 28)Cardiovascular Epidemiology Unit, Department of Public Health and Primary Care, University of Cambridge, Cambridge, UK; 29)Clinical Pharmacology, William Harvey Research Institute, Barts and The London School of Medicine and Dentistry, Queen Mary University of London, London, UK; 30)Research Unit of Molecular Epidemiology, Institute of Epidemiology, Helmholtz Zentrum München Research Center for Environmental Health, Neuherberg, Germany; 31)Institute of Epidemiology, Helmholtz Zentrum München, German Research Center for Environmental Health, Neuherberg, Germany; 32)German Center for Diabetes Research (DZD), München-Neuherberg, Germany; 33)Independent Research Group Clinical Epidemiology, Helmholtz Zentrum München, German Research Center for Environmental Health, Neuherberg, Germany; 34)Institute of Medical Informatics, Biometry and Epidemiology, Chair of Epidemiology and Chair of Genetic Epidemiology, Ludwig-MaximiliansUniversität, Munich, Germany; 35)Department of Medicine I, University Hospital Grosshadern, Ludwig-Maximilians-University, Munich, Germany; 36)Institute of Genetic Epidemiology, Helmholtz Zentrum München, German Research Center for Environmental Health, Neuherberg, Germany; 37)Institute of Medical Biostatistics, Epidemiology and Informatics (IMBEI), University Medical Center, Johannes Gutenberg University, Mainz, Germany; 38)Cardiovascular Medicine Unit, Department of Medicine, Solna, Karolinska Institutet, Stockholm, Sweden; 39)Center for Molecular Medicine, Karolinska University Hospital Solna, Stockholm, Sweden; 40)Institute of Health and Wellbeing, University of Glasgow, Glasgow, UK; 41)Health Data Research UK; 42)Cardiovascular Medicine, Radcliffe Department of Medicine, University of Oxford, Oxford, UK; 43)Wellcome Centre 
medRxiv preprint doi: https://doi.org/10.1101/2021.04.17.21255471; this version posted April 20, 2021. The copyright holder for this preprint (which was not certified by peer review) is the author/funder, who has granted medRxiv a license to display the preprint in perpetuity. All rights reserved. No reuse allowed without permission.

for Human Genetics, University of Oxford, Oxford, UK; 44)Department of Biostatistics, Boston

University School of Public Health, Boston, Massachusetts, USA; 45)Department of Biostatistics and Center for Statistical Genetics, University of Michigan, Ann Arbor, Michigan, USA; 46)New England Biolabs, 240 County Road, Ipswich, Massachusetts, USA; 47)Vanderbilt Translational and Clinical Cardiovascular Research Center, Nashville, Tennessee, USA; 48)Department of Epidemiology, Erasmus Medical Center, Rotterdam, the Netherlands; 49)Department of Internal Medicine, Erasmus Medical Center, Rotterdam, the Netherlands; 50)NIHR Barts Cardiovascular Biomedical Research Centre, Barts and The London School of Medicine and Dentistry, Queen Mary University of London, London, UK; 51)Ulm University Medical Centre, Department of Internal Medicine I, Ulm, Germany; 52)Department of Public Health and General Practice, Norwegian University of Science and Technology, Trondheim, Norway; 53)Department of Community Medicine, Faculty of Health Sciences, University of Troms $\varnothing$, Troms $\varnothing$, Norway; 54)Department of Clinical Medicine, Faculty of Health Sciences, University of Troms $\varnothing$, Troms $\varnothing$, Norway; 55)Department of Genetics, University of North Carolina, Chapel Hill, North Carolina, USA; 56)Deutsches Herzzentrum München, Technische Universität München, Munich, Germany; 57)DZHK (German Centre for Cardiovascular Research), partner site Munich Heart Alliance, Munich Germany; 58)Institute of Epidemiology and Medical Biometry, University of Ulm, Ulm, Germany; 59)Lee Kong Chian School of Medicine, Nanyang Technological University Singapore, Singapore and Department of Endocrinology, Tan Tock Seng Hospital, Singapore; 60)Section of Cell Biology and Functional Genomics, Imperial College London, London, UK; 61)Department Bioengineering, Imperial College London, Bessemer Building, South Kensington Campus, London, UK; 62)EXCEED (Exeter Centre of Excellence for Diabetes Research), University of Exeter Medical School, Exeter, UK; 63)Public Health Promotion Unit, Finnish Institute for Health and Welfare, Helsinki, Finland; 64)Department of Public Health, University of Helsinki, Helsinki, Finland; 65)Diabetes Research Unit, King Abdulaziz University, Jeddah, Saudi Arabia; 66)Center for Genomic Medicine and Diabetes Unit, Massachusetts General Hospital, Boston, Massachusetts, USA; 67)Programs in Metabolism and Medical and Population Genetics, Broad 
medRxiv preprint doi: https://doi.org/10.1101/2021.04.17.21255471; this version posted April 20, 2021. The copyright holder for this preprint (which was not certified by peer review) is the author/funder, who has granted medRxiv a license to display the preprint in perpetuity. All rights reserved. No reuse allowed without permission.

105

106

107

108

109

110

111

112

113

114

115

116

117

118

119

120

121

122

124

125

Institute, Massachusetts, USA; 68)Department of Medicine, Harvard Medical School, Boston, Massachusetts, USA; 69)Department of Public Health and Primary Care, University of Cambridge, Cambridge, UK; 70)Centre for Medical Systems Biology, Leiden, the Netherlands; 71)Nuffield Department of Population Health, University of Oxford, Oxford, UK; 72)Netherlands Consortium for healthy ageing, the Hague, the Netherlands; 73)QIMR Berghofer Medical Research Institute, Brisbane Australia; 74)Institute for Molecualr Bioscience, The University of Queensland, St Lucia, Australia; 75)Department of Life Sciences and Biotechnology, University of Ferrara, Ferrara, Italy; 76)MRC Centre for Environment and Health, Imperial College, London, UK; 77)National Institute for Health Research Imperial College London Biomedical Research Centre, Imperial College London, UK; 78)Faculty of Medicine, University of Iceland, Reykjavík, Iceland; 79)Vanderbilt University Medical Center and the Vanderbilt Translational and Clinical Cardiovascular Research Center, Nashville, Tennessee, USA; 80)Oxford Centre for Diabetes, Endocrinology and Metabolism, University of Oxford, Oxford, United Kingdom; 81)Oxford National Institute for Health Research Biomedical Research Centre, Churchill Hospital, Oxford, United Kingdom; 82)UMR 8199 - EGID, Institut Pasteur de Lille, CNRS, University of Lille, F-59000 Lille, France; 83)Drug Discovery Biology, Monash Institute of Pharmaceutical Sciences, Monash University, Parkville, Victoria, Australia ; 84)ARC Centre for Cryo-electron Microscopy of Membrane Proteins, Monash Institute of Pharmaceutical Sciences, Monash University, Parkville, Victoria, Australia; 85)Finnish Institute for Molecular Medicine (FIMM), Helsinki University, Helsinki, Finland; 86)General Medicine Division, Massachusetts General Hospital, Boston, Massachusetts, USA; 87)Department of Genetics, University Medical Center Groningen, the Netherlands; 88)School of Life Sciences, University of Essex, Colchester, UK; 89)Laboratory of Glycogenomics, Institute of Cytology and Genetics SD RAS, Prospekt Akademika Lavrent'yeva 10, Novosibirsk, Russia; 90)PolyOmica, 's-Hertogenbosch, The Netherlands.

\section{Correspondence should be addressed to:}

\section{Prof Inga Prokopenko}


medRxiv preprint doi: https://doi.org/10.1101/2021.04.17.21255471; this version posted April 20, 2021. The copyright holder for this preprint (which was not certified by peer review) is the author/funder, who has granted medRxiv a license to display the preprint in perpetuity.

131 Section of Statistical Multi-Omics,

132 Department of Clinical and Experimental Medicine, University of Surrey

133 Leggett Building, Daphne Jackson Road, Manor Campus,

134 Guildford, Surrey, UK, GU2 7WG

135 Phone: +441483684900 ;

136 Email: i.prokopenko@surrey.ac.uk

Dr Ben Jones

139 Section of Endocrinology and Investigative Medicine

140 Imperial College London

141 Du Cane Road

142 London, UK, W12 0NN

143 Phone: +442033130348

144 Email: ben.jones@imperial.ac.uk

145

146 Dr Marika Kaakinen

147 Section of Statistical Multi-Omics,

148 Department of Clinical and Experimental Medicine, University of Surrey

149 Leggett Building, Daphne Jackson Road, Manor Campus,

150 Guildford, Surrey, UK, GU2 7WG

151 Phone: +441483683365 ;

152 Email: $\underline{\text { m.kaakinen@surrey.ac.uk }}$ 
medRxiv preprint doi: https://doi.org/10.1101/2021.04.17.21255471; this version posted April 20, 2021. The copyright holder for this preprint (which was not certified by peer review) is the author/funder, who has granted medRxiv a license to display the preprint in perpetuity. All rights reserved. No reuse allowed without permission.

\section{Abstract}

Homeostatic control of blood glucose requires different physiological responses in the fasting and post-prandial states. We reasoned that glucose measurements under non-standardised conditions (random glucose; RG) may capture diverse glucoregulatory processes more effectively than previous genome-wide association studies (GWAS) of fasting glycaemia or after standardised glucose loads. Through GWAS meta-analysis of RG in 493,036 individuals without diabetes of diverse ethnicities we identified 128 associated loci represented by 162 distinct signals, including 14 with sex-dimorphic effects, 9 discovered through trans-ethnic analysis, and 70 novel signals for glycaemic traits. Novel RG loci were particularly enriched in expression in the ileum and colon, indicating a prominent role for the gastrointestinal tract in the control of blood glucose. Functional studies and molecular dynamics simulations of coding variants of GLP1R, a well-established type 2 diabetes treatment target, provided a genetic framework for optimal selection of GLP-1R agonist therapy. We also provided new evidence from Mendelian randomisation that lung function is modulated by blood glucose and that pulmonary dysfunction is a diabetes complication. Thus, our approach based on RG GWAS provided wide-ranging insights into the biology of glucose regulation, diabetes complications and the potential for treatment stratification.

Main text

175 Genetic factors are important determinants of glucose homeostasis and type 2 diabetes (T2D) susceptibility. Heritability of both fasting glucose (FG) and T2D is high, at $35-40 \%{ }^{1}$ and $30-$ $60 \%^{2}$, respectively. To date, more than 400 genetic loci have been described for $T 2 \mathrm{D}^{3,4}$. 
medRxiv preprint doi: https://doi.org/10.1101/2021.04.17.21255471; this version posted April 20, 2021. The copyright holder for this preprint (which was not certified by peer review) is the author/funder, who has granted medRxiv a license to display the preprint in perpetuity. All rights reserved. No reuse allowed without permission.

178 Genome-wide association studies (GWAS) for glycaemic traits in individuals without diabetes

179 have identified genetic predictors of blood glucose, insulin and other metabolic responses during fasting or after oral or intravenous glucose challenge tests ${ }^{5-8}$. However, physiological

181 glucose regulation involves responses to diverse nutritional and other stimuli that were, by design, omitted from such studies. Blood glucose is frequently measured at different times throughout the day in clinical practice and research studies (random glucose; RG). Whilst RG is inherently more variable than standardised measures, we reasoned that, across a very large number of individuals, it may more comprehensively represent complex glucoregulatory processes occurring in different organ systems. Therefore, to identify and functionally validate genetic effects influencing RG, explore its relationships with other traits and diseases, and utilise these data to inform approaches to T2D treatment stratification, we performed the first large-scale trans-ethnic GWAS meta-analysis for RG in individuals without diabetes.

RG GWAS significantly expands the catalogue of glycaemia-related genetic associations

We undertook RG GWAS in 493,036 individuals without diabetes of European $(n=479,482)$ and other ethnic $(n=16,554)$ descent with adjustment for age, sex and time since last meal (where available), along with exclusion of extreme hyperglycaemia (RG>20 mmol/L) and individuals with diabetes (Supplementary Table 1). The covariate selection was done upon extensive phenotype modelling (Methods, Supplementary Table 2, Supplementary Figure 1a). We identified 162 distinct signals $\left(P<10^{-5}\right)$ within 128 genetic loci reaching genome-wide significance $\left(P<5 \times 10^{-8}\right)$ (Figure 1a, Supplementary Table 3 ). Seventy RG signals had not previously been reported for glycaemic traits (Table 1, Supplementary Table 3). In Europeans, while the UK Biobank (UKBB) study provided $83.8 \%$ of the total study size, 128 detected 
medRxiv preprint doi: https://doi.org/10.1101/2021.04.17.21255471; this version posted April 20, 2021. The copyright holder for this preprint (which was not certified by peer review) is the author/funder, who has granted medRxiv a license to display the preprint in perpetuity. All rights reserved. No reuse allowed without permission.

signals out of the 143 were directionally consistent in UKBB and other contributing studies grouped together (Supplementary Table 3). Adjustment for last meal timing (Supplementary Figure 1b) reduced effect sizes for several loci, including ITPR3, RREB1, RGS17, RFX6/VGLL2 and SYNGAP1, suggesting that these may be more related to the post-prandial state. RREB1, RFX6 are transcription factors implicated in the development and function of pancreatic beta cells ${ }^{9,10}$, and ITPR3 is a calcium channel involved in islet calcium dynamics in response to glucose and G protein-coupled receptor (GPCR) activation ${ }^{11}$. Neither adjustment for bodymass index (BMI), nor a more stringent hyperglycaemia cut-off (RG>11.1 mmol/L or $\mathrm{HbA1c} \geq 6.5 \%$ ) (Supplementary Figure 1c-e) materially changed the magnitude and significance of the RG effect estimates, although when all covariate models were individually applied, nine additional signals at genome-wide significance were identified in UKBB (Table

\section{1, Supplementary Table 4).}

Several of the 162 signals identified in Europeans showed nominal significance $(P<0.05)$ in specific UKBB ethnic groups, with GCK ( $r$ 2908286, $\mathrm{r}^{2}{ }_{1000 \text { GenomesAllEthnicities }}=0.83$ with $\mathrm{rs} 2971670$ lead in Europeans) reaching genome-wide significance in the African descent individuals alone (Supplementary Table 3). Among the novel RG signals, USP47 was nominally significant in the individuals of African, FAM46 and ACVR1C in the Indian and TRIM59/KPNA4 and ZC3H13 in Chinese UKBB ancestry. Trans-ethnic meta-analyses combining Europeans and the other four UKBB ancestral groups revealed seven novel RG signals, including those at FOXN3, EPS 8 and ISG2OL2 (Table 1). Overall, while being only 16,554 individuals larger in sample size than the European meta-analysis, the trans-ethnic analysis expanded the novel locus discovery for RG by one tenth (Supplementary Table 5). 
medRxiv preprint doi: https://doi.org/10.1101/2021.04.17.21255471; this version posted April 20, 2021. The copyright holder for this preprint (which was not certified by peer review) is the author/funder, who has granted medRxiv a license to display the preprint in perpetuity. All rights reserved. No reuse allowed without permission.

Among established glycaemic trait signals, the well-known FG loci G6PC2 $\left(P<5.86 \times 10^{-754}\right)$ and GCK $\left(P<6.93 \times 10^{-301}\right)$, with key roles in gluconeogenesis ${ }^{12}$ and glucose sensing ${ }^{13}$, respectively, showed the strongest associations with RG (Supplementary Table 3). We also observed two thirds of RG signals overlapping with T2D-risk loci (Supplementary Figure 1e), including SLC30A8, DGKB, TCF7L2, GRB10 and THADA. The direction of effects at these loci between

RG, T2D and homeostasis model assessment of beta-cell function/insulin resistance (HOMA-

$B /-I R)^{6}$ (Supplementary Figures 1e-f and 2, Supplementary Table 6) were consistent with their epidemiological correlation. Notably, 14 established $^{14,15}$, such as DGKB, THADA, RSPO3, G6PC2, and novel, including TRIM59, POP7, SLC43A2, and SGIP1, loci showed sex-dimorphic effects (Methods, Table 1, Figure 1a, Supplementary Table 3). Fine-mapping the associations at RG loci through conditional analysis (Table 1) we found three independent coding nonsynonymous rare (minor allele frequency, $M A F<1 \%$ ) variants at G6PC2 with predicted (rs2232326) and established (rs138726309, rs2232323) ${ }^{16}$ deleterious effects (Supplementary

Table 7). Within GCK, we observed five rare independent $\left(r^{2} 1000\right.$ GenomesAllethnicities $\left.<0.001\right)$ nonrs2908276 for T2D, glycaemic traits or obesity (Supplementary Table 7).

Next, we sought to pinpoint the most plausible set of causal variants by calculating $99 \%$ credible sets for each of RG loci. In the Europeans only analysis, 19 RG signals were explained by one variant with posterior probability of $\geq 99 \%$ of being causal. For another 20 signals, a lead variant had a posterior probability $>80 \%$ (Figure $\mathbf{1 b}$, Supplementary Table $\mathbf{8}$ ). The credible sets were narrowed down in trans-ethnic RG meta-analysis (median credible set size 12.5 in the Europeans only, and 11.0 in the trans-ethnic analysis) (Supplementary Tables 9 and 10). This analysis helped to prioritise GLP1R for functional studies, in addition to the 
medRxiv preprint doi: https://doi.org/10.1101/2021.04.17.21255471; this version posted April 20, 2021. The copyright holder for this preprint (which was not certified by peer review) is the author/funder, who has granted medRxiv a license to display the preprint in perpetuity. All rights reserved. No reuse allowed without permission.

already deeply characterised G6PC2 and $C C N D 2^{17}$, all three with lead SNPs of low frequency $(1 \% \leq \mathrm{MAF}<5 \%)$ and posterior probability $>99 \%$ of being causal.

The lead RG-associated SNPs at GLP1R, NEUROD1, and EDEM3 loci in our analysis were lowfrequency coding variants (Supplementary Figure 3). NEUROD1 (Neuronal Differentiation 1) and EDEM3 (ER Degradation Enhancing Alpha-Mannosidase Like Protein 3) are plausible candidates for glucose homeostasis with the former reported for glucosuria ${ }^{18}$ and the latter linked to renal function ${ }^{19,20}$. Additionally, lead variants at three previously reported for FG (GCKR, TET2 and RREB1) and two novel RG (NMT1, WIPI1) loci were all common (MAF $\geq 5 \%$ ) coding variants (Supplementary Figure 3).

Functional and structural characterisation of RG-associated GLP1R coding variants provides a possible framework for T2D treatment stratification

The GLP1R gene, identified in our analysis and in previous $T 2 D^{21}$ and glycaemic trait ${ }^{22}$ GWAS, encodes a class B G protein-coupled receptor (glucagon-like peptide-1 receptor; GLP-1R) that is an established target for glucose-lowering and weight loss in T2D using drugs such as exenatide (exendin-4) and semaglutide ${ }^{23}$. Within GLP1R, the lead missense variant at rs10305492 (A316T) had a strong (0.058 mmol/I per allele) RG-lowering effect, second by size only to G6PC2 locus variants. Previous attempts to functionally characterise A316T and further GLP1R variants experimentally have been inconclusive ${ }^{24}$, so we adopted a strategy based on measuring ligand-induced coupling to mini- $\mathrm{Ga}_{\mathrm{s}}{ }^{25}$, representing the most proximal part of the $\mathrm{Ga}_{\mathrm{s}}$-adenylate cyclase-cyclic adenosine monophosphate (cAMP) pathway that links GLP-1R activation to insulin secretion. Mini-G $\alpha_{s}$ coupling efficiency was predictive of RG 
medRxiv preprint doi: https://doi.org/10.1101/2021.04.17.21255471; this version posted April 20, 2021. The copyright holder for this preprint (which was not certified by peer review) is the author/funder, who has granted medRxiv a license to display the preprint in perpetuity. All rights reserved. No reuse allowed without permission.

effect for 16 GLP1R coding variants detected in the UKBB dataset with effect allele frequency ranging from common (G168S, rs6923761, $P=4.40 \times 10^{-5}$ ) to rare (R421W, rs146868158, $P=0.054$ ) (Figure 2a, Supplementary Table 11), thereby linking differences in experimentally measured GLP-1R function to blood glucose homeostasis.

To probe whether GLP1R coding variation could be therapeutically as well as physiologically relevant, we also measured responses to several endogenous and pharmacological GLP-1R agonists. Focussing on the two directly genotyped GLP1R missense variants in UKBB, we observed that A316T (rs10305492-A) showed increased responses, and R421W (rs146868158-T) showed reduced responses, to all ligands except exendin-4 (both variants) and semaglutide (A316T only), in line with their RG effects (Figure 2b). Agonist-induced GLP$1 \mathrm{R}$ endocytosis with R421W was normal despite its signalling deficit, suggestive of biased agonism $^{26}$. The imputed common G168S variant, with relatively small RG-lowering effect ( $\beta=-$ $\left.0.0013\left[S E=3.14 \times 10^{-4}\right]\right)$, also showed subtle increases in function.

To gain structural insights into GLP1R variant effects we performed molecular dynamics simulations of the human GLP-1R bound to oxyntomodulin ${ }^{27}$ (Extended Data Tables 1-6). A316T has a single amino acid substitution in the core of the receptor transmembrane domain (Figure 2c) that leads to an alteration of the hydrogen bond network in close proximity (Video S1). In A316T, residue $\mathrm{T} 316^{5.46}$ replaced $\mathrm{Y} 242^{3.45}$ in a persistent hydrogen bond with the backbone of P312 5.42 one turn of the helix above T316 5.46 (Figures 2 d-e, Video S1). This triggers a local structural rearrangement that could transmit to the intracellular $\mathrm{G}$ protein binding site through transmembrane helix 3 (TM3) and TM5. A structural water molecule was found close to position 5.46 in both A316T and WT (water cluster $\alpha 5$, Figure $\mathbf{2 f}$ ). The same 
medRxiv preprint doi: https://doi.org/10.1101/2021.04.17.21255471; this version posted April 20, 2021. The copyright holder for this preprint (which was not certified by peer review) is the author/funder, who has granted medRxiv a license to display the preprint in perpetuity. All rights reserved. No reuse allowed without permission.

water bridged the backbone of $\mathrm{Y} 241^{3.44}$ and $\mathrm{A} 316^{5.46}$ in $\mathrm{WT}$, or the backbone of $\mathrm{Y} 241^{3.44}$ and the side chain of T316 5.46 in A316T. Given the importance of conserved water networks in the process of activation of class A GPCRs ${ }^{28,29}$, the presence of a stable hydrated spot close to position $5.46^{30}$ corroborates this site as important for tuning the intracellular conformational landscape of GLP-1R. Also, a stabilising role for the water molecules at the binding site of the from a previous analysis of A316T dynamics ${ }^{22}$, which used an early model that does not fully capture the full structural features of the current active GLP-1R models.

In analogy with A316T, molecular simulations with the G168S variant indicate the formation of a stable new hydrogen bond between the side chain of residue $\mathrm{S} 168^{1.63}$ and $\mathrm{A} 164^{1.59}$, located one turn above on the same helix (Video S2, Figure $\mathbf{2 g}$ ). This moved the C-terminal end of TM1 closer to TM2 and reduced the overall flexibility of ICL1 (Figure $\mathbf{2 h}$ ), which could potentially alter the role of ICL1 in G protein activation. In contrast to A316T and G168S, the site of mutation R421W is consistent with persistent interactions with the G protein. Simulations predicted a propensity of R421W to interact with a different region of the G protein $\beta$-subunit to that engaged by WT (Figure $\mathbf{2 i}$ ).

317 missense variants identified from exome sequencing ${ }^{31}$ for exendin-4-induced mini- $\mathrm{G}_{\mathrm{s}}$ coupling and endocytosis (Figures 2j-k, Supplementary Table 12). 110 variants showed a

319 reduced response in either or both pathways ("LoF1"), and 67 displayed a specific response deficit that was not fully explained by differences in GLP-1R surface expression ("LoF2"), with many of these defects being larger than in the analysis in Figure $\mathbf{2 a}$. 
medRxiv preprint doi: https://doi.org/10.1101/2021.04.17.21255471; this version posted April 20, 2021. The copyright holder for this preprint (which was not certified by peer review) is the author/funder, who has granted medRxiv a license to display the preprint in perpetuity.

323 Overall, these data suggest GLP1R variation influences blood glucose levels in health and is

324 likely to be a direct modifier of responses to drug treatment ${ }^{32}$. As some patients fail to 325 respond adequately to GLP-1R agonist treatment, and others are particularly sensitive to side 326 effects ${ }^{33}$, this approach may feed into optimised treatment selection in T2D.

Functional annotation of RG associations and intestinal health

330 Previous T2D and glycaemic trait GWAS have primarily implicated pancreatic, adipose and

331 liver tissues ${ }^{3}$. To leverage our RG GWA results to identify additional cell and tissue types with aetiological roles in glucose metabolism, we performed a range of complementary functional annotation analyses in relation to RG GWAS. DEPICT ${ }^{34}$, which predicts enriched tissue types from prioritised gene sets (Methods), highlighted intestinal tissues including ileum and colon, as well as pancreas, adrenal glands, adrenal cortex and cartilage (False Discovery Rate<0.20) prioritisation based on single cell RNAseq datasets (Methods), identified large intestinal tissue as the second ranked only to pancreatic cell types (Figure 3c, Supplementary Table 14); interestingly, RG variants were related particularly to enriched expression in pancreatic polypeptide (PP) cells, exceeding even the more conventionally implicated insulin-secreting

341 beta cells. Supporting evidence was obtained from transcriptome-wide association study

342 (TWAS) analysis (Methods), where we identified a total of 216 (119 unique) significant 343 genetically driven associations across the ten tested tissues; 52 (26 unique) of highlighted genes are located at genome-wide significant RG loci (Supplementary Tables 15a). TWAS signals in skeletal muscle showed the largest overlap with RG signals, such as GPSM1 ${ }^{36}$ and 
medRxiv preprint doi: https://doi.org/10.1101/2021.04.17.21255471; this version posted April 20, 2021. The copyright holder for this preprint (which was not certified by peer review) is the author/funder, who has granted medRxiv a license to display the preprint in perpetuity. All rights reserved. No reuse allowed without permission.

WARS; with combined results from ileum and colon also highly enriched, including the novel NMT1 and the established FADS1/3 and MADD genes (Figure 1a, Supplementary Tables 15ab). Moreover, epigenetic annotations using the GARFIELD tool highlighted significant $\left(P<2.5 \times 10^{-5}\right.$, Methods) enrichment of RG-associated variants in foetal large intestine, as well as blood, liver and other tissues (Supplementary Figure 4, Supplementary Table 16). Adult intestinal tissues are not available in GARFIELD except for colon. Prompted by multiple analyses highlighting a potential role for the digestive tract in glucose regulation, we assessed the overlap between our signals and those from the latest microbiome GWAS ${ }^{37}$ (Methods) and identified three genera sharing signals with RG at two loci: Collinsella and LachnospiraceaeFCSO20 at ABO-FUT2 and Slackia at G6PC2 (Figure 1a, Supplementary Table 17). The ABO-FUT2 locus effects on RG could be mediated by abundance of bacteria producing glucose from lactose and galactose ${ }^{38}$.

eQTL colocalization analyses, using eQTLgen blood expression data from 31,684 individuals ${ }^{39}$ and the COLOC2 approach (Methods), identified 14 loci with strong links (posterior probability $>50 \%$ ) to gene expression data, including SMC4, TRIM59, EIF5A2, TET2, COG5, CHMP5, NFX1, FNBP4, MADD, RAPSN, WARS1, HBM, NUFIP2, and PPDPF (Supplementary Table 18). This further supported elucidation of biological candidates at novel and established glycaemic loci.

Finally, we observed associations at two RG loci (GCKR, HNF1A) with nine total plasma Nglycome traits ${ }^{40}$ at a Bonferroni corrected threshold (Methods, Figure 1a, Supplementary Table 19). These traits represent highly branched galactosylated sialylated glycans (attached to alpha1-acid protein - an acute-phase $\operatorname{protein}^{41}$ ), known to lead to chronic low-grade 
medRxiv preprint doi: https://doi.org/10.1101/2021.04.17.21255471; this version posted April 20, 2021. The copyright holder for this preprint (which was not certified by peer review) is the author/funder, who has granted medRxiv a license to display the preprint in perpetuity. All rights reserved. No reuse allowed without permission.

inflammation ${ }^{42,43}$ and an increased risk of $T 2 \mathrm{D}^{44-46}$ that might be explained by the role of $\mathrm{N}$ glycan branching of the glucagon receptor in the glucose homeostasis ${ }^{47}$. In addition, ten glycans showed association with five RG loci (GCKR, HNF1A, BAG1, PLUT, ACVR1C) loci at a suggestive level of significance (Figure 1a). Among them, three are attached to immunoglobulin $\mathrm{G}$ molecules ${ }^{41}$ and their increased relative abundances are associated with a lower risk of T2D $\mathrm{D}^{48}$ and diminished inflammation status ${ }^{49}$.

\section{Analysis of genetic relationships between RG and other metabolic or non-metabolic traits}

To quantify the shared genetic contribution between RG and other phenotypes, we estimated their genetic correlations using linkage-disequilibrium score regression analyses. We detected positive genetic correlations between RG, squamous cell lung cancer $\left(r_{\mathrm{g}}=0.28\right.$, $P=0.0015)$, and lung cancer $\left(r_{g}=0.12, P=0.037\right.$, Figure 4, Supplementary Table 20); as well as inverse genetic correlations with lung function related traits, such as forced vital capacity (FVC, $\left.r_{g}=-0.090, P=0.0059\right)$ and forced expiratory volume in 1 second (FEV1, $r_{g}=-0.054$, $P=0.017$ ) (Figures 3a and 4, Supplementary Table 20). To investigate this further, we conducted a bi-directional Mendelian Randomisation (MR) analysis, which suggested a causal effect of RG and T2D on lung function, including FEV1 ( $\beta_{M R-R G}=-0.60, P=0.0015 ; \beta_{M R-T 2 D}=-0.049$, $\left.P=1.27 \times 10^{-13}\right)$ and FVC $\left(\beta_{M R-R G}=-0.61, P=3.5 \times 10^{-4} ; \beta_{M R-T 2 D}=-0.062, P=1.42 \times 10^{-21}\right)$, but not vice versa (Methods, Supplementary Table 21). Previous observational studies have highlighted worsening lung function, as defined by FVC, in T2D patients ${ }^{50,51}$. More recently, it was shown that patients with diabetes are at an increased risk of death from the viral infection COVID$19^{52}$, with pulmonary dysfunction contributing to mortality ${ }^{53}$. Our data therefore support the 
medRxiv preprint doi: https://doi.org/10.1101/2021.04.17.21255471; this version posted April 20, 2021. The copyright holder for this preprint (which was not certified by peer review) is the author/funder, who has granted medRxiv a license to display the preprint in perpetuity. All rights reserved. No reuse allowed without permission.

393

394

395

396

397

398

399

400

401

402

403

404

405

406

407

408

409

410

411

412

413

414

415

416

causal effect of glycaemic dysregulation on a decline in lung function as a novel complication of diabetes.

Genome-wide genetic correlation analyses also showed strong positive genetic correlation of RG with FG $\left(r_{g}=0.88, P=6.93 \times 10^{-61}\right.$, Figure 4, Supplementary Table 20). We meta-analysed RG studies other than UKBB with FG GWAS summary statistics ${ }^{54}$, observing 77 signals reaching nominal significance that were directionally consistent in both UKBB and RG+FG (Supplementary Table 3), providing an additional support to our RG findings. Given the large genetic overlap between RG, other glycaemic traits and T2D, we evaluated the ability of a trait-specific polygenic risk score (PRS) to predict RG, T2D and glycated haemoglobin (HbA1c) levels using UKBB effect estimates and the Vanderbilt cohort (Methods). The RG PRS explained $0.58 \%$ of the variance in RG levels when individuals with T2D were included, (Supplementary Table 22 ) and $0.71 \%$ of the variance after excluding those who developed T2D within one year of their last RG measurement. The RG PRS performance was comparable to that of the FG loci PRS $(0.38 \%$ vs. $0.42 \%$ for T2D; $0.40 \%$ vs. $0.44 \%$ for $\mathrm{HbA} 1 \mathrm{c}$ ) indicating wide similarities with the latter.

We previously highlighted diverse effects of FG and T2D loci on pathophysiological processes related to T2D development by grouping associated loci in relation to their effects on multiple phenotypes ${ }^{6}$. Cluster analysis of the RG signals with 45 related phenotypes identified three separate clusters that give insights into the aetiology of glucose regulation and associated disease states (Methods, Figure 1a, Supplementary Table 23, Supplementary Figures 5a-d). Cluster 1 ("metabolic syndrome" cluster) clearly separated 33 loci with effects on higher waist-to-hip ratio, blood pressure, plasma triglycerides, insulin resistance (HOMA-IR) and 
medRxiv preprint doi: https://doi.org/10.1101/2021.04.17.21255471; this version posted April 20, 2021. The copyright holder for this preprint (which was not certified by peer review) is the author/funder, who has granted medRxiv a license to display the preprint in perpetuity. All rights reserved. No reuse allowed without permission.

coronary artery disease risk, as well as lower testosterone and sex hormone binding globulin

418 levels in men. Cluster 3 was characterised in particular by insulin secretory defects ${ }^{6}$. Cluster 2

419 was less clearly defined by a primary effect on insulin release versus insulin action ${ }^{3}$, but

420 interestingly included a sub-cluster of 21 loci which exert protective effects on inflammatory

421 bowel disease. Moreover, cluster 2 was notable for generally reduced impact on T2D risk in

422 comparison to clusters 1 and 3, underscoring the partial overlap between genetic

423 determinants of glycaemia and T2D that is known to exist ${ }^{55}$.

Discussion

426

427 Taking advantage of data from 493,036 individuals, we have expanded by 58 the number of

428 loci associated with glycaemic traits. By using RG, our analysis integrates genetic contributions

429 to a wider range of physiological stages than possible with FG or other standardised measures. Moreover, the greater statistical power obtained from large trans-ethnic metaanalysis improves confidence in identification of potentially causal variants, thereby helping to prioritise loci for more detailed functional analyses in the future. Our observation of ligandspecific responses to the A316T, G168S and R421W GLP1R variants provides a mechanism

434 that can explain why some individuals respond better or worse to particular GLP-1R-targeting drugs. We note that other class B GPCRs identified in our current analysis and other glycaemic or T2D GWAS include GIPR, GLP2R ${ }^{3}$ and $S C T R^{21}$, all of which are investigational targets for T2D treatment. Our functional annotation analyses point to underexplored tissue mediators of glycaemic regulation, with several sources of evidence highlighting a likely role of the intestine. This observation is compatible with the well-described and profound effects of gastric bypass surgery on T2D resolution ${ }^{56}$, as well as links between the intestinal microbiome 
medRxiv preprint doi: https://doi.org/10.1101/2021.04.17.21255471; this version posted April 20, 2021. The copyright holder for this preprint (which was not certified by peer review) is the author/funder, who has granted medRxiv a license to display the preprint in perpetuity. All rights reserved. No reuse allowed without permission.

441 and responses to several diabetes drugs ${ }^{57}$. Finally, through Mendelian randomisation we

442 were able to identify a causal effect of glucose levels and T2D on lung function, demonstrating

443 the utility of this approach for the corroboration of findings from observational studies and

444 elevating lung dysfunction as a new complication of diabetes. 
medRxiv preprint doi: https://doi.org/10.1101/2021.04.17.21255471; this version posted April 20, 2021. The copyright holder for this preprint (which was not certified by peer review) is the author/funder, who has granted medRxiv a license to display the preprint in perpetuity.

\section{Phenotype definition and model selection for RG GWAS}

We used RG (mmol/l) measured in plasma or in whole blood (corrected to plasma level using the correction factor of 1.13). Individuals were excluded from the analysis, if they had a diagnosis of T2D or were on diabetes treatment (oral or insulin). Individual studies applied further sample exclusions, including pregnancy, fasting plasma glucose equal to or greater than $7 \mathrm{mmol} / \mathrm{l}$ in a separate visit, when available, and having type 1 diabetes. Detailed descriptions of study-specific RG measurements are given in Supplementary Table 1. All studies were approved by local ethics committees and all participants gave informed consent.

We examined the distributions of untransformed and natural logarithmic transformed RG in the first set of six available cohorts. We observed that RG was approximately normally distributed after natural log transformation. We then determined the variables that could have a significant effect on RG by fitting several regression models using naturally logtransformed RG as the outcome with age, sex, BMI and time since last meal as predictors. Modelling of RG revealed significant effects $(P<0.05)$ of age, sex, $\mathrm{BMI}$ and time since last meal

461 (accounted for as $T, T^{2}$ and $T^{3}$ ) in these cohorts (Supplementary Table 2). Compared to RG models without $T$, inclusion of $T, T^{2}$ and $T^{3}$ increased the proportion of variance explained in the range of $1-6 \%$. Thus, inclusion of this covariate is potentially equivalent to $1-6 \%$ increase in study sample size. For the GWAS, we included individuals based on two RG cut-offs: $<20$ $\mathrm{mmol} / \mathrm{l}(20)$ to account for the effect of extreme RG values and $<11.1 \mathrm{mmol} / \mathrm{l}(11)$, which is an established threshold for T2D diagnosis. We then evaluated six different models in GWAS according to covariates included and cut-offs used: 1 ) age (A) and sex (S), RG<20 mmol/L 
medRxiv preprint doi: https://doi.org/10.1101/2021.04.17.21255471; this version posted April 20, 2021. The copyright holder for this preprint (which was not certified by peer review) is the author/funder, who has granted medRxiv a license to display the preprint in perpetuity. All rights reserved. No reuse allowed without permission.

469

470

471

472

\section{Genotyping and quality control}

474 Commercial genome-wide arrays and the Metabochip ${ }^{58}$ were used by individual studies for 475 genotyping. Studies with genome-wide arrays undertook imputation of missing genotypes imputation quality>0.4.

(AS11), 4) age, sex and BMI, RG<11.1 mmol/L (ASB11), 5) age, sex, $T, T^{2}$ and $T^{3}, R G<20 \mathrm{mmol} / \mathrm{L}$ (AST20) and 6) age, sex, T, $\mathrm{T}^{2}$ and $\mathrm{T}^{3}$ and $\mathrm{BMI}, \mathrm{RG}<20 \mathrm{mmol} / \mathrm{L}$ (ASTB20). Apart from above, additional adjustments for study site and geographical covariates were also applied. using at least the HapMap II CEU reference panel via $\mathrm{MACH}^{59}$, IMPUTE ${ }^{60}$ or MINIMAC ${ }^{61}$ software (Supplementary Table 1). For each study, samples reflecting duplicates, low call rate, gender mismatch, or population outliers were removed. Low-quality SNPs were excluded by the following criteria: call rate $<0.95$, minor allele frequency $(\mathrm{MAF})<0.01$, minor allele count $<10$, Hardy-Weinberg $P$-value $<10^{-4}$. GWAS were performed with PLINK, SNPTEST, EMMAX, R package LMEKIN, Merlin, STATA, and ProbABEL (Supplementary Table 1).

\section{GWAS in the UKBB}

For the GWAS of the UKBB data we excluded non-white non-European individuals and those with discrepancies in genotyped and reported sex. For the RG definition, we used the same criteria as in the other studies described above. To control for population structure, we adjusted the analyses for six first principal components. The GWAS was performed using the BOLT-LMM V2.3 software ${ }^{62,63}$ restricting the analyses to variants with $M A F>1 \%$ and 
medRxiv preprint doi: https://doi.org/10.1101/2021.04.17.21255471; this version posted April 20, 2021. The copyright holder for this preprint (which was not certified by peer review) is the author/funder, who has granted medRxiv a license to display the preprint in perpetuity. All rights reserved. No reuse allowed without permission. component to all-ancestries 1000 Genomes reference panel ${ }^{64}$ using summary statistics imputation method implemented in the SS-Imp v0.5.5 software ${ }^{65}$. SNPs with imputation quality score $<0.7$ were excluded. We then conducted inverse variance meta-analyses to combine the association summary statistics from all components using METAL (version from 2011-03-25) ${ }^{66}$. We focused our meta-analyses on models AS20 (17 cohorts, $N_{\max }=481,150$ ) and AST20 (when time from last meal was available in the cohort) (12 cohorts, $\mathrm{N}_{\max }=438,678$ ).

For FHS cohort, where no information was available for individuals with RG $>11.1$ (an established threshold for $2 \mathrm{hGlu}$ concentration, which is a criterion for T2D diagnosis), AS11 model results were used. In order to maximise the association power while taking into AS20+AST20 in the following text (17 cohorts, $\left.N_{\max }=480,250\right)$. $\left(P<5 \times 10^{-8}\right)$ in the meta-analysis of UKBB and other cohorts in either of our two models of interest (AS20) or (AST20) or in their combination (AS20+AST20). We report the $P$-value from

513 the combined model, unless otherwise stated. Full results from all models are provided in the

514 Supplementary Table 3. All the follow-up analyses were conducted using the combined 
medRxiv preprint doi: https://doi.org/10.1101/2021.04.17.21255471; this version posted April 20, 2021. The copyright holder for this preprint (which was not certified by peer review) is the author/funder, who has granted medRxiv a license to display the preprint in perpetuity. All rights reserved. No reuse allowed without permission.

516 of the effect sizes for the selected leads in the combined model in UKBB results vs other

517 cohort results. We further extended the check between UKBB results and meta-analysis of

518 other cohorts including FG GWAS meta-analysis ${ }^{54}$ excluding overlapping cohorts. This meta-

519 analysis conducted in METAL was sample size and $P$-value based due to the measures being

520 at different scale (natural logarithm transformed RG and untransformed FG).

521

522 Trans-ethnic analyses and meta-analysis

523 We performed GWAS in those non-European populations within UKBB that had a sample size

524 of at least 1,500 individuals. These were Black $(N=7,644)$, Indian $(N=5,660)$, Pakistani $525(\mathrm{~N}=1,747)$ and Chinese $(\mathrm{N}=1,503)$. We further meta-analysed our European cohorts with the 526 trans-ethnic UKBB cohorts. The analyses were performed with BOLT-LMM and METAL.

527

528 Sex-dimorphic analysis

529 To evaluate sex-dimorphism in our results, we meta-analysed the UKBB and the Vanderbilt 530 cohort with the GMAMA software ${ }^{67}$, which provides a 2 degrees of freedom (df) test of 531 association assuming different effect sizes between the sexes. We considered a signal to show 532 evidence of sex-dimorphism if the $2 \mathrm{df}$ test $P$-value was $<5 \times 10^{-8}$ and if the sex heterogeneity $533 \quad P$-value $(1 \mathrm{df})$ was $<0.05$.

535 Clumping and GCTA analysis

536 We performed a standard clumping analysis [PLINK 1.9 (v1.90b6.4) $)^{68}$ criteria: $P \leq 5 \times 10^{-8}$, $537 r^{2}=0.01$, window-size $=1 \mathrm{Mb}, 1000$ Genomes Phase 3 data as linkage disequilibrium (LD) 538 reference panel] to select a list of near-independent signals. We then performed a stepwise 539 model selection analysis (GCTA conditional analysis) to replicate the analysis using GCTA 
medRxiv preprint doi: https://doi.org/10.1101/2021.04.17.21255471; this version posted April 20, 2021. The copyright holder for this preprint (which was not certified by peer review) is the author/funder, who has granted medRxiv a license to display the preprint in perpetuity. All rights reserved. No reuse allowed without permission.

540 v1.93.069 with the following parameters: $P \leq 5 \times 10^{-8}$ and window-size $=1 \mathrm{Mb}$. We further

541 checked for additional distinct signals by using a region-wide threshold of $P \leq 1 \times 10^{-5}$ for 542 statistical significance.

543

544 GLP-1R pharmacological and structural analysis

545 Reagents

546 Custom peptides were purchased from Wuxi Apptec and were at least 95\% pure. SNAP-

547 Surface probes were purchased from New England Biolabs. BG-S-S- $649^{70}$ was provided by

548 New England Biolabs on a collaborative basis. Furimazine was obtained from Promega.

549

550 Plasmids and cell line generation

551 Wild-type and variant GLP-1R expression plasmids, termed pcDNA5-SNAPf-GLP-1R-SmBiT,

552 were generated by Genewiz, as previously described ${ }^{71}$, to the following design: a fast-labelling $553 \mathrm{SNAP}_{f}$ tag and upstream signal peptide based on that of the $5-\mathrm{HT}_{3 \mathrm{~A}}$ receptor

554 (MDSYLLMWGLLTFIMVPGCQA), plus C-terminal SmBiT tag, were appended to the codonoptimised wild-type or variant human GLP-1R sequence (without the endogenous N-terminal signal peptide, which would lead to cleavage of the N-terminal SNAP-tag; accordingly, known missense variants in the signal peptide region were not included), and inserted into the pcDNA5/FRT/TO expression vector. These constructs allow bio-orthogonal labelling of expressed GLP-1R using SNAP-labelling probes and monitoring of cytosolic protein

560 interactions made to GLP-1R. Constructs were used either for transient transfection or to

561 generate stable cell lines. To obtain cell populations with inducible expression of SNAP-GLP-

562 1R-SmBiT from a single genomic locus, Flp-In ${ }^{T M}$ T-REx ${ }^{T M} 293$ cells $^{72}$ (Thermo Fisher) were co563 transfected with pOG44 (Thermo Fisher) and wild-type or variant pcDNA5-SNAPf-GLP-1R- 
medRxiv preprint doi: https://doi.org/10.1101/2021.04.17.21255471; this version posted April 20, 2021. The copyright holder for this preprint (which was not certified by peer review) is the author/funder, who has granted medRxiv a license to display the preprint in perpetuity. All rights reserved. No reuse allowed without permission.

564

565

566

567

568

569

570

571

572

573

574

575

576

577

578

579

580

581

582

583

584

585

586

SmBiT in a 9:1 ratio, followed by selection with $100 \mu \mathrm{g} / \mathrm{ml}$ hygromycin. The resulting cell lines were maintained in DMEM supplemented with $10 \%$ foetal bovine serum (FBS) and $1 \%$ penicillin/streptomycin.

\section{Mini-Gs recruitment assay}

Assays were performed as previously described ${ }^{71}$. Where stable cell lines were used (i.e. Figures $\mathbf{2 a}$ and $\mathbf{2 b}$ ), wild-type or variant T-REx-SNAP-GLP-1R-SmBiT cells were seeded in 12well plates and transfected with $1 \mu \mathrm{g} /$ well LgBiT-mini- $\mathrm{G}_{\mathrm{s}}{ }^{25}$ (a gift from Prof Nevin Lambert, Medical College of Georgia). The following day GLP-1R expression was induced by addition of tetracycline $(0.2 \mu \mathrm{g} / \mathrm{ml})$ to the culture medium for 24 hours. For transient transfection assays (i.e. Figure 2j), HEK293T cells in poly-D-lysine-coated white 96-well plates were transfected using Lipofectamine 2000 with $0.05 \mu \mathrm{g} /$ well wild-type or variant SNAP-GLP-1R-SmBiT plus $0.05 \mu \mathrm{g} /$ well $\mathrm{LgBiT}-$ mini-Gs and the assay performed 24 hours later. Cells were then resuspended in Hank's balanced salt solution (HBSS) + furimazine (Promega) diluted 1:50 and seeded in 96-well half area white plates, or the same reagent added to adherent cells for transient transfection assays. Baseline luminescence was measured over 5 min using a Flexstation 3 plate reader at $37^{\circ} \mathrm{C}$ before addition of ligand or vehicle. Agonists were applied at a series of concentrations spanning the response range. After agonist addition, luminescent signal was serially recorded over $30 \mathrm{~min}$, and ligand-induced effects were quantified by subtracting individual well baseline. Signals were corrected for differences in cell number as determined by BCA assay.

\section{High content imaging-based GLP-1R internalisation assay}


medRxiv preprint doi: https://doi.org/10.1101/2021.04.17.21255471; this version posted April 20, 2021. The copyright holder for this preprint (which was not certified by peer review) is the author/funder, who has granted medRxiv a license to display the preprint in perpetuity. All rights reserved. No reuse allowed without permission.

587

588

589

590

591

592

593

594

595

596

597

598

599

600

601

602

603

604

605

606

607

608

609

610

The assay was performed as previously described ${ }^{71}$. Where stable cell lines were used (i.e.

Figures $\mathbf{2 a}$ and $\mathbf{2 b}$ ), wild-type or variant T-REx-SNAP-GLP-1R-SmBiT cells were seeded $(10,000 /$ well $)$ in poly-D-lysine-coated black, clear-bottom 96-well plates, in complete medium supplemented with tetracycline $(0.2 \mu \mathrm{g} / \mathrm{ml})$ for 24 hours before the assay. Medium was removed and cells labelled with $0.5 \mu \mathrm{M}$ BG-S-S-649 (a gift from New England Biolabs) in complete medium for $20 \mathrm{~min}$ at $37^{\circ} \mathrm{C}$. Agonists were then applied in serum-free medium at the indicated dose for a 30-min stimulation period to induce GLP-1R internalisation. A series of concentrations spanning the response range were used. Cells were then washed with HBSS, followed by a 5 -min treatment $\pm 100 \mathrm{mM}$ sodium 2-mercaptoethanesulfonate (Mesna) in alkaline TNE buffer ( $\mathrm{pH}$ 8.6) to cleave residual surface BG-S-S-649 without affecting that internalised whilst bound to SNAP-GLP-1R. After re-washing, the plate was imaged using a 0.75 numerical aperture 20x phase contrast objective, with 9 fields-of-view (FOVs) per well acquired for both transmitted phase contrast and epifluorescence. Flat-field correction of epifluorescence images was performed using $\mathrm{BaSiC}^{73}$ and cell segmentation was performed using PHANTAST ${ }^{74}$ for the phase contrast image. To determine specific GLP-1R labelling, cellfree background per image was determined from the segmented epifluorescence image and subtracted from the mean fluorescence intensity from the cell-containing regions. Ligand induced effects were determined by subtracting the signal from vehicle-treated cells exposed to Mesna. Responses were normalised to signal from labelled, untreated cells (i.e. total surface labelling) within the same assay. GLP-1R surface expression levels were also obtained from these assays from wells not treated with GLP-1RA or Mesna. For transient transfection assays (i.e. Figure $\mathbf{2 j}$ ), the assay was performed similarly but with the following changes: 1 ) HEK293T cells in poly-D-lysine-coated black clear-bottom 96-well plates were transfected using Lipofectamine 2000 with $0.1 \mu \mathrm{g} /$ well wild-type or variant SNAP-GLP-1R-SmBiT and the 
medRxiv preprint doi: https://doi.org/10.1101/2021.04.17.21255471; this version posted April 20, 2021. The copyright holder for this preprint (which was not certified by peer review) is the author/funder, who has granted medRxiv a license to display the preprint in perpetuity. All rights reserved. No reuse allowed without permission.

assay performed 24 hours later; 2) the plate was imaged as above both prior to and after

612 ligand treatment (+subsequent Mesna cleavage); 3) surface labelling quantification was

613 obtained from the pre-treatment read, and total internalised receptor was obtained from the

614 post-treatment read.

615

\section{Analysis of pharmacological data}

617 Technical replicates within the same assay were averaged to give one biological replicate. For concentration-response assays (Figures $\mathbf{2 a}$ and $\mathbf{2 b}$ ), ligand-induced responses were analysed by 3-parameter fitting in Prism 8.0 (GraphPad Software). As a composite measure of agonism ${ }^{75}, \log _{10}$-transformed $E_{\max } / E_{50}$ values were obtained for each ligand/variant

621 response. The wild-type response was subtracted from the variant response to give $\Delta \log \left(\max / E_{50}\right)$, a measure of gain- or loss-of-function for the variant relative to wild-type. $\log _{10}$-transformed surface expression levels were obtained for each variant relative to wildtype; these were then used to correct mini- $_{s} \Delta \log \left(\max / \mathrm{EC}_{50}\right)$ values for differences in variant GLP-1R surface expression levels, by subtraction with error propagation. GLP-1R internalisation responses were already normalised to surface expression within each assay.

627 Statistical significance between wild-type and variant responses was inferred if the 95\% 628 confidence intervals for $\Delta \log \left(\max / E C_{50}\right)$ did not cross zero ${ }^{75}$. Changes to the profile of receptor response between mini-Gs recruitment and GLP-1R internalisation were inferred if $630 \mathrm{p}<0.05$ with unpaired t-test analysis, with Holm-Sidak correction for multiple comparisons.

631 For transient transfection assays (Figure $\mathbf{2} \mathbf{j}$ ), responses were normalised to wild-type 632 response and $\log _{10}$ transformed to give Log $\Delta$ response. Additionally, the impact of differences 633 in surface expression on functional responses was determined by subtracting log634 transformed normalised expression level from log-transformed normalised response. 
medRxiv preprint doi: https://doi.org/10.1101/2021.04.17.21255471; this version posted April 20, 2021. The copyright holder for this preprint (which was not certified by peer review) is the author/funder, who has granted medRxiv a license to display the preprint in perpetuity.

Variance explained in RG effects by mini-Gs recruitment at coding GLP1R variants

637 RG (AST20) effects estimated in the UKBB study at 18 independent $\left(r^{2}<0.02\right)$ coding GLP1R

638 variants (Supplementary Table 10) were regressed on mini-Gs coupling in response to GLP-1

639 stimulation (corrected for surface expression) giving more weight to variants with higher

640 minor allele frequency. Adjusted $R^{2}$ is reported as variance explained in RG effects by mini-

$641 \mathrm{G}_{\mathrm{s}}$ coupling.

642

643 Computational methods including molecular dynamics simulations

644 The active state structure of GLP-1R in complex with $\mathrm{OXM}^{27}$ and Gs protein was modelled as 645 previously described ${ }^{30}$ and used to simulate the WT GLP-1R and G168S, A316T and R421W.

646 The systems were prepared for molecular dynamics (MD) simulations and equilibrated as

647 reported $\mathrm{in}^{30}$. AceMD3 ${ }^{76}$ was employed for production runs (four MD replicas of 500 ns each).

648 AquaMMapS analysis ${ }^{77}$ was performed as previously described ${ }^{30}$.

649

650 Credible set analysis

651 After selecting the signals with each region based on different M-A results from AS20, AST20

652 and AS20+AST20 models, we further performed a credible set analysis to obtain a list of

653 potential causal variants for each of the 143 selected signals. Based on the method adopted

654 from $^{78}$ under the assumption that there is one causal variant within each region, we created

$65599 \%$ credible sets. We also calculated credible sets for the trans-ethnic meta-analysis and

656 compared the results between the European only and trans-ethnic meta-analyses.

657

658

DEPICT analysis 
medRxiv preprint doi: https://doi.org/10.1101/2021.04.17.21255471; this version posted April 20, 2021. The copyright holder for this preprint (which was not certified by peer review) is the author/funder, who has granted medRxiv a license to display the preprint in perpetuity. All rights reserved. No reuse allowed without permission.

DEPICT uses GWAS summary statistics and computes a prioritization of genes in associated

660 loci, which are used to prioritise tissues via enrichment analysis. DEPICT v1 (rel 194) was used

661 with default settings and RG GWAS summary statistics as input against a genetic background

662 of SNPsnap data ${ }^{79}$ derived from the 1000 Genomes Project Phase $3^{80}$ in order to prioritise

663 genes. Tissue and cell types enriched for prioritised genes were computed on normalised

664 expression data comprised of 209 tissues and cell types from 37,427 Affymetrix U133 Plus 2.0

665 Array, as previously described ${ }^{34}$. We used 500 permutations for bias adjustment and 50 replications for false discovery rate estimation in our analysis in order to calculate empirical $P$ -

667 values and false discovery rate cutoffs for prioritised tissues.

668

\section{CELLECT analysis}

670 CELL type Expression-specific integration for Complex Traits (CELLECT) ${ }^{35}$ v1.0.0 and Cell type

671 EXpression-specificity (CELLEX) ${ }^{35}$ v1.0.0 are two toolkits for genetic identification of likely

672 etiologic cell types using GWAS summary statistics and single-cell RNA-sequencing (scRNA-

673 seq) data. Tabula muris gene expression data ${ }^{81}$, a scRNA-seq dataset derived from 20 organs

674 from adult male and female mice, was pre-processed as described previously ${ }^{82}$. Briefly,

675 expression values were normalised by using a scaling factor of $10 \mathrm{k}$ transcripts. The normalised

676 values were transformed by taking $\log (x+1)$, followed by filtering out infrequently expressed

677 genes, and keeping only those mouse transcripts with 1-1 mapping to human genes in

678 Ensembl v.91. This data was supplied to CELLEX to compute a cumulative expression

679 specificity metric $(\mathrm{ES} \mu)$ of every gene for each Tabula muris cell type by combining four

680 different expression specificity measures ${ }^{82}$. ES $\mu$ values were converted to stratified LD-score 
medRxiv preprint doi: https://doi.org/10.1101/2021.04.17.21255471; this version posted April 20, 2021. The copyright holder for this preprint (which was not certified by peer review) is the author/funder, who has granted medRxiv a license to display the preprint in perpetuity. All rights reserved. No reuse allowed without permission.

682

\section{3}

684

\section{5}

686

687

688

689

690

691

692

693

694

695

696

697

698

699

700

701

702

to the strongest ES $\mu$ value within $100 \mathrm{~kb}$. Cell types were prioritised by S-LDSC on the basis of ES $\mu$-derived annotations and GWAS summary statistics from the current RG meta-analysis.

\section{Genetically regulated gene expression analysis}

We used MetaXcan (S-PrediXcan) v0.6.10 $10^{83}$ to identify genes whose genetically predicted gene expression levels are associated with RG in a number of tissues. The tested tissues were chosen based on their involvement in glucose metabolism. Those were adipose visceral omentum, adipose subcutaneous, skeletal muscle, liver, pancreas and whole blood. Additionally, we tested ileum, transverse colon, sigmoid colon and adrenal gland, because they were highlighted by DEPICT analysis. The models for the tissues of interest were trained with GTEx Version 7 transcriptome data from European individuals ${ }^{84}$. The tissue transcriptome models and 1000 Genomes $^{85}$ based covariance matrices of the SNPs used within each model were downloaded from PredictDB Data Repository. The association statistics between predicted gene expression and RG were estimated from the effects and their standard errors coming from the AS20+AST20 model. Only statistically significant associations after Bonferroni correction for the number of genes tested across all tissues $(P \leq$ $8.996 \times 10^{-7}$ ) were included into the table. Genes, where less than $80 \%$ of the SNPs used in the model were found in the GWAS summary statistics, were excluded due to low reliability of association result.

\section{GARFIELD analysis}

We applied the GARFIELD tool $v 2^{86}$ on the RG AS20+AST20 meta-analysis results to assess enrichment of the RG-associated variants within functional and regulatory features. GARFIELD integrates various types of data from a number of publicly available cell lines. Those 
medRxiv preprint doi: https://doi.org/10.1101/2021.04.17.21255471; this version posted April 20, 2021. The copyright holder for this preprint (which was not certified by peer review) is the author/funder, who has granted medRxiv a license to display the preprint in perpetuity. All rights reserved. No reuse allowed without permission.

706

707 factor binding sites, FAIRE-seq elements and histone modifications. We considered 708

709

710

\section{Genetic association with gut microbiome}

712 We assessed the genetic overlap between RG GWAS results and those for gut microbiome.

713 GWAS of microbiome profiles were publicly available and downloaded from the

714 https://mibiogen.gcc.rug.nl/ [mibiogen.gcc.rug.nl]. For each of the 211 taxa, the 715 716

717

718

719

720

721

722

723

724

725

726

727

728

729 corresponding $P$-values for the 143 RG GWAS SNPs and their proxies were extracted.

\section{Genetic association with GLP-1 and GIP}

We assessed the genetic overlap between RG GWAS results and those for glucagon-like peptide-1 (GLP-1) and gastric inhibitory polypeptide (GIP) measured at 0 and 120 minutes. We extracted the results for the 143 RG signals from the GWAS summary statistics for GLP-1 and $G \mathrm{PP}^{87}$.

\section{eQTL co-localization analysis}

We further performed co-localization analysis using whole blood gene expression-QTL (eQTL) data provided by eQTLGen ${ }^{39}$ and AS20+AST20 meta-analysis results. Only cis-eQTL data from eQTLGen was incorporated to reduce the computational burden. The COLOC2 Bayesianbased method ${ }^{88}$ was used to interrogate the potential co-localization between RG GWAS signals and the genetic control of gene expression. We first extracted the RG GWAS test statistics of all the SNPs within +/-1Mb region around the 143 RG signals. Then, for each RG 
medRxiv preprint doi: https://doi.org/10.1101/2021.04.17.21255471; this version posted April 20, 2021. The copyright holder for this preprint (which was not certified by peer review) is the author/funder, who has granted medRxiv a license to display the preprint in perpetuity. All rights reserved. No reuse allowed without permission.

signal, we matched the eQTLGen results with the RG results and performed COLOC2 analysis evaluating the posterior probability (PP) of five hypotheses for each region: $H_{0}$, no association; $H_{1}$, GWAS association only; $H_{2}$, eQTL association only; $H_{3}$, both GWAS and eQTL association, but not co-localised; and $\mathrm{H}_{4}$, both GWAS and eQTL association and co-localised.

Only GWAS signals with at least one nearby gene/probe reaching PP $\left(\mathrm{H}_{4}\right) \geq 0.5$ were reported.

\section{Genetic association with human blood plasma N-glycosylation}

737 We assessed the genetic association between 143 RG signals and 113 human blood plasma

$738 \mathrm{~N}$-glycome traits using previously published genome-wide summary association statistics ${ }^{89}$. The description of the analysed traits and details of the association analysis can be found elsewhere ${ }^{40}$. We considered associations to be significant when $P$ value $<0.05 / 113 / 143=3.09 \mathrm{e}-6$ (after Bonferroni correction). Association was considered as suggestive when $P$-value $<10^{-4}$.

\section{Genetic correlation analysis}

745 We investigate the shared genetic component between RG and other traits, including

746 glycaemic ones, by performing genetic correlation analysis using the bivariate LD score

747 regression method (LDSC v1.0.0) ${ }^{90}$. To reduce multiple testing burden, only the GWAS results

748 of the UKBB model AS20 were used. We used GWAS summary statistics available in LDhub ${ }^{91}$

749 and the Meta-Analysis of Glucose and Insulin-related Traits Consortium (MAGIC) website

750 (https://www.magicinvestigators.org) for several traits including FG/FI54, HOMA-B/HOMA-

751 IR ${ }^{92}$. In total, 228 different traits were included in the genetic correlation analysis with RG.

752 We considered $P \leq 0.05$ as the nominal significant level. 
medRxiv preprint doi: https://doi.org/10.1101/2021.04.17.21255471; this version posted April 20, 2021. The copyright holder for this preprint (which was not certified by peer review) is the author/funder, who has granted medRxiv a license to display the preprint in perpetuity. All rights reserved. No reuse allowed without permission.

We applied a bidirectional two-sample MR strategy to investigate causality between RG and lung function, as well as T2D and lung function using independent genetic variants as instruments. MR can provide estimates of the effect of modifiable exposures on an outcome (e.g. disease) unaffected by classical confounding or reverse causation, whenever randomised clinical trials are not feasible. We looked for evidence for the presence of a causal effect of RG and T2D on two lung function phenotypes; FVC and FEV1 in a two-sample MR setting. cohorts from the SpiroMeta consortium and the UKBB study. T2D susceptibility variants and their effects were obtained from the largest-to-date T2D GWAS . To avoid confounding due to sample overlap, lung function summary statistics used as outcome data were those estimated in the SpiroMeta consortium alone. Similarly, when testing the effect of lung function on RG, RG genetic effects used as outcome data were estimated in all cohorts except UK Biobank. There was no sample overlap between the lung function- and the T2D GWAS, thus allowing the use of T2D effects estimated in all contributing

769 European studies. Genome-wide T2D summary statistics were available from a previous study ${ }^{3}$ to test for the causal effect of lung function on T2D. All analyses were conducted using the R software package TwoSampleMR v0.5.4 ${ }^{94}$. Instrument selection: Independent (established by conditional analyses for both RG and the lung function phenotypes) genome-wide significant $\left(P<5 \times 10^{-8}\right)$ variants were selected as genetic instruments. In total, 143 independent variants were defined for RG by the current study, 424 T2D signals were reported for Europeans by Vujkovic et al. and 130/162 independent signals were reported by Shrine et al. for FVC and FEV1, respectively. We looked

777 for proxy variants with a minimum $r^{2}$ of 0.8 where the instrumental variant was not present 
medRxiv preprint doi: https://doi.org/10.1101/2021.04.17.21255471; this version posted April 20, 2021. The copyright holder for this preprint (which was not certified by peer review) is the author/funder, who has granted medRxiv a license to display the preprint in perpetuity. All rights reserved. No reuse allowed without permission.

778

779

780

781

782

783

784

785

786

787

788

789

790

791

792

793

794

795

796

797

798

799

800

801

in the outcome data. Palindromic variants with minor allele frequency larger than $45 \%$ were excluded to avoid uncertainty when harmonizing effects to the exposure-increasing allele. After filtering, 136 variants were used to instrument RG and 413 variants were available as T2D instruments. For FVC, 125 and 115 variants could be used as instruments in the RG and T2D MR analyses, respectively. For FEV1, 157 and 140 variants served as instruments in the RG and T2D MR analyses, respectively.

Causal effects were estimated using the inverse-variance weighted method, which combines the causal estimates of individual instrumental variants (Wald ratios) in a random-effects meta-analysis ${ }^{95}$. As a sensitivity analysis, we employed MR-Egger regression to obtain causal estimates that are more robust to the inclusion of invalid instruments ${ }^{96}$.

\section{PRS analysis}

We tested the ability of the RG genetic effects to predict RG, T2D and HbA1c. We compared that to the predictive power of T2D and FG genetic instruments by computing PRS for RG, T2D and FG and assessing their performance in predicting RG, T2D and HbA1c. PRS analyses require base- and target data from independent populations. The base datasets in our analyses were UKBB-only estimates from the present RG GWAS, meta-analysis estimates of 32 studies for $\mathrm{T}^{2} \mathrm{D}^{97}$ and meta-analysis estimates from the MAGIC for $\mathrm{FG}^{54}$. We used the second largest cohort, the Vanderbilt University Medical Centre (VUMC), as our target dataset. PRS construction and model evaluation were done using the software PRSice $(v 2.2 .3)^{98}$. The PRS for an individual is the summation of the effect (trait-increasing) alleles weighted by the effect size of the SNP taken from the base data. The SNPs in the base data are clumped so that they are largely independent of each other and thus their effects can be summed. To assess predictive power, PRS for RG, T2D and FG were regressed onto the 
medRxiv preprint doi: https://doi.org/10.1101/2021.04.17.21255471; this version posted April 20, 2021. The copyright holder for this preprint (which was not certified by peer review) is the author/funder, who has granted medRxiv a license to display the preprint in perpetuity.

808 derived by subtracting the $\mathrm{R}^{2}$ from the null model (Phenotype $\sim$ sex + age +4 principal

810 principal components + batch) which contains the PRS at the best predicting P-value threshold.

\section{Clustering of the RG signals with results for $\mathbf{4 5}$ other phenotypes}

814 We looked up the Z-scores (regression coefficient beta divided by the standard error) of the distinct 143 RG signals in publicly available summary statistics of 45 relevant phenotypes. All variant effects were aligned to the RG risk allele. HapMap2 based summary statistics were

817 imputed using SS-Imp v0.5.5 ${ }^{65}$ to minimise missingness. Missing summary statistics values

818 were imputed via mean imputation. The resulting variant-trait association matrix was scaled

819 by the square root of the study's mean sample size. We used agglomerative hierarchical clustering with Ward's method to partition the variants into groups by their effects on the

821 considered outcomes. The clustering analysis was performed in R using function hclust() from in-built stats package. 
medRxiv preprint doi: https://doi.org/10.1101/2021.04.17.21255471; this version posted April 20, 2021. The copyright holder for this preprint (which was not certified by peer review) is the author/funder, who has granted medRxiv a license to display the preprint in perpetuity. All rights reserved. No reuse allowed without permission.

GWAS summary statistics for RG analyses presented in this manuscript will be deposited on

https://www.magicinvestigators.org/downloads/ and will be also be available through the

NHGRI-EBI GWAS Catalog https://www.ebi.ac.uk/gwas/downloads/summary-statistics.

828

\section{References}

8301 1. Santos, R.L. et al. Heritability of fasting glucose levels in a young genetically isolated population. Diabetologia 49, 667-72 (2006).

832

833

834

835

836

837

838

839

840

841

842

843

844

845

846

847

848

849

850

851

852

853

854

855

856

857

2. Almgren, P. et al. Heritability and familiality of type 2 diabetes and related

quantitative traits in the Botnia Study. Diabetologia 54, 2811-9 (2011).

3. Scott, R.A. et al. An Expanded Genome-Wide Association Study of Type 2 Diabetes in Europeans. Diabetes 66, 2888-2902 (2017).

4. Vujkovic, M. et al. Discovery of 318 new risk loci for type 2 diabetes and related vascular outcomes among 1.4 million participants in a multi-ancestry meta-analysis. Nat Genet 52, 680-691 (2020).

5. Chen, J. et al. The Trans-Ancestral Genomic Architecture of Glycaemic Traits. bioRxiv, 2020.07.23.217646 (2020).

6. Dimas, A.S. et al. Impact of type 2 diabetes susceptibility variants on quantitative glycemic traits reveals mechanistic heterogeneity. Diabetes 63, 2158-71 (2014).

7. Ingelsson, E. et al. Detailed physiologic characterization reveals diverse mechanisms

for novel genetic Loci regulating glucose and insulin metabolism in humans. Diabetes

8. Scott, R.A. et al. Large-scale association analyses identify new loci influencing

glycemic traits and provide insight into the underlying biological pathways. Nat Genet 44, 991-1005 (2012).

9. Deng, Y.N., Xia, Z., Zhang, P., Ejaz, S. \& Liang, S. Transcription Factor RREB1: from Target Genes towards Biological Functions. Int J Biol Sci 16, 1463-1473 (2020).

10. Piccand, J. et al. Rfx6 maintains the functional identity of adult pancreatic beta cells. Cell Rep 9, 2219-32 (2014).

11. Tsuboi, T. et al. Glucagon-like peptide-1 mobilizes intracellular $\mathrm{Ca} 2+$ and stimulates mitochondrial ATP synthesis in pancreatic MIN6 beta-cells. Biochem J 369, 287-99 (2003).

12. Bosma, K.J. et al. Pancreatic islet beta cell-specific deletion of G6pc2 reduces fasting blood glucose. J Mol Endocrinol 64, 235-248 (2020).

13. Rutter, G.A., Georgiadou, E., Martinez-Sanchez, A. \& Pullen, T.J. Metabolic and functional specialisations of the pancreatic beta cell: gene disallowance, mitochondrial metabolism and intercellular connectivity. Diabetologia 63, 1990-1998 (2020).

14. Hara, K. et al. Genome-wide association study identifies three novel loci for type 2 diabetes. Hum Mol Genet 23, 239-46 (2014).

864 15. Morris, A.P. et al. Large-scale association analysis provides insights into the genetic architecture and pathophysiology of type 2 diabetes. Nat Genet 44, 981-90 (2012). 
medRxiv preprint doi: https://doi.org/10.1101/2021.04.17.21255471; this version posted April 20, 2021. The copyright holder for this preprint (which was not certified by peer review) is the author/funder, who has granted medRxiv a license to display the preprint in perpetuity. All rights reserved. No reuse allowed without permission.

16. Mahajan, A. et al. Identification and functional characterization of G6PC2 coding variants influencing glycemic traits define an effector transcript at the G6PC2ABCB11 locus. PLoS Genet 11, e1004876 (2015).

17. Pullen, T.J. \& Rutter, G.A. Roles of IncRNAs in pancreatic beta cell identity and diabetes susceptibility. Front Genet 5, 193 (2014).

18. Benonisdottir, S. et al. Sequence variants associating with urinary biomarkers. Hum Mol Genet 28, 1199-1211 (2019).

19. Teumer, A. et al. Genome-wide association meta-analyses and fine-mapping elucidate pathways influencing albuminuria. Nat Commun 10, 4130 (2019).

20. Wuttke, M. et al. A catalog of genetic loci associated with kidney function from analyses of a million individuals. Nat Genet 51, 957-972 (2019).

21. Spracklen, C.N. et al. Identification of type 2 diabetes loci in 433,540 East Asian individuals. Nature 582, 240-245 (2020).

22. Wessel, J. et al. Low-frequency and rare exome chip variants associate with fasting glucose and type 2 diabetes susceptibility. Nat Commun 6, 5897 (2015).

23. Tomkin, G.H. Treatment of type 2 diabetes, lifestyle, GLP1 agonists and DPP4 inhibitors. World J Diabetes 5, 636-50 (2014).

24. Koole, C. et al. Polymorphism and ligand dependent changes in human glucagon-like peptide-1 receptor (GLP-1R) function: allosteric rescue of loss of function mutation. Mol Pharmacol 80, 486-97 (2011).

25. Wan, Q. et al. Mini G protein probes for active $\mathrm{G}$ protein-coupled receptors (GPCRs) in live cells. J Biol Chem 293, 7466-7473 (2018).

26. Jones, B. et al. Targeting GLP-1 receptor trafficking to improve agonist efficacy. Nat Commun 9, 1602 (2018).

27. Deganutti, G. et al. Dynamics of GLP-1R peptide agonist engagement are correlated with kinetics of G protein activation. bioRxiv, 2021.03.10.434902 (2021).

28. Venkatakrishnan, A.J. et al. Diverse GPCRs exhibit conserved water networks for stabilization and activation. Proc Natl Acad Sci U S A 116, 3288-3293 (2019).

29. Yuan, S., Filipek, S., Palczewski, K. \& Vogel, H. Activation of G-protein-coupled receptors correlates with the formation of a continuous internal water pathway. Nat Commun 5, 4733 (2014).

30. Zhao, P. et al. Activation of the GLP-1 receptor by a non-peptidic agonist. Nature 577, 432-436 (2020).

31. Karczewski, K.J. et al. The mutational constraint spectrum quantified from variation in 141,456 humans. Nature 581, 434-443 (2020).

32. Hauser, A.S. et al. Pharmacogenomics of GPCR Drug Targets. Cell 172, 41-54 e19 (2018).

33. Sorli, C. et al. Efficacy and safety of once-weekly semaglutide monotherapy versus placebo in patients with type 2 diabetes (SUSTAIN 1): a double-blind, randomised, placebo-controlled, parallel-group, multinational, multicentre phase 3a trial. Lancet Diabetes Endocrinol 5, 251-260 (2017).

34. Pers, T.H. et al. Biological interpretation of genome-wide association studies using predicted gene functions. Nat Commun 6, 5890 (2015).

35. Timshel, P.N., Thompson, J.J. \& Pers, T.H. Genetic mapping of etiologic brain cell types for obesity. Elife $\mathbf{9}(2020)$.

36. Ding, Q. et al. Genome-wide meta-analysis associates GPSM1 with type 2 diabetes, a plausible gene involved in skeletal muscle function. J Hum Genet 65, 411-420 (2020). 
medRxiv preprint doi: https://doi.org/10.1101/2021.04.17.21255471; this version posted April 20, 2021. The copyright holder for this preprint (which was not certified by peer review) is the author/funder, who has granted medRxiv a license to display the preprint in perpetuity. All rights reserved. No reuse allowed without permission.

37. Kurilshikov, A. et al. Genetics of human gut microbiome composition. bioRxiv, 2020.06.26.173724 (2020).

38. Lopera-Maya, E.A. et al. Effect of host genetics on the gut microbiome in 7,738 participants of the Dutch Microbiome Project. bioRxiv, 2020.12.09.417642 (2020).

39. Võsa, U. et al. Unraveling the polygenic architecture of complex traits using blood eQTL metaanalysis. bioRxiv, 447367 (2018).

40. Sharapov, S.Z. et al. Defining the genetic control of human blood plasma N-glycome using genome-wide association study. Hum Mol Genet 28, 2062-2077 (2019).

41. Clerc, F. et al. Human plasma protein N-glycosylation. Glycoconj J 33, 309-43 (2016).

42. Novokmet, M. et al. Changes in IgG and total plasma protein glycomes in acute systemic inflammation. Sci Rep 4, 4347 (2014).

43. Schmidt, M.I. et al. Markers of inflammation and prediction of diabetes mellitus in adults (Atherosclerosis Risk in Communities study): a cohort study. Lancet 353, 164952 (1999).

44. Dotz, V. et al. Plasma protein N-glycan signatures of type 2 diabetes. Biochim Biophys Acta Gen Subj 1862, 2613-2622 (2018).

45. Keser, T. et al. Increased plasma N-glycome complexity is associated with higher risk of type 2 diabetes. Diabetologia 60, 2352-2360 (2017).

46. Wittenbecher, C. et al. Plasma N-Glycans as Emerging Biomarkers of Cardiometabolic Risk: A Prospective Investigation in the EPIC-Potsdam Cohort Study. Diabetes Care 43, 661-668 (2020).

47. Johswich, A. et al. N-glycan remodeling on glucagon receptor is an effector of nutrient sensing by the hexosamine biosynthesis pathway. J Biol Chem 289, 1592741 (2014).

48. Lemmers, R.F.H. et al. IgG glycan patterns are associated with type 2 diabetes in independent European populations. Biochim Biophys Acta Gen Subj 1861, 2240-2249 (2017).

49. Liu, D. et al. Ischemic stroke is associated with the pro-inflammatory potential of Nglycosylated immunoglobulin G. J Neuroinflammation 15, 123 (2018).

50. Kopf, S. et al. Breathlessness and Restrictive Lung Disease: An Important DiabetesRelated Feature in Patients with Type 2 Diabetes. Respiration 96, 29-40 (2018).

51. Sonoda, N. et al. A prospective study of the impact of diabetes mellitus on restrictive and obstructive lung function impairment: The Saku study. Metabolism 82, 58-64 (2018).

52. Abdi, A., Jalilian, M., Sarbarzeh, P.A. \& Vlaisavljevic, Z. Diabetes and COVID-19: A systematic review on the current evidences. Diabetes Res Clin Pract 166, 108347 (2020).

53. Zhu, L. et al. Association of Blood Glucose Control and Outcomes in Patients with COVID-19 and Pre-existing Type 2 Diabetes. Cell Metab 31, 1068-1077 e3 (2020).

54. Lagou, V. et al. Sex-dimorphic genetic effects and novel loci for fasting glucose and insulin variability. Nat Commun 12, 24 (2021).

55. Marullo, L., El-Sayed Moustafa, J.S. \& Prokopenko, I. Insights into the genetic susceptibility to type 2 diabetes from genome-wide association studies of glycaemic traits. Curr Diab Rep 14, 551 (2014).

56. Mingrone, G. et al. Metabolic surgery versus conventional medical therapy in patients with type 2 diabetes: 10 -year follow-up of an open-label, single-centre, randomised controlled trial. Lancet 397, 293-304 (2021). 
medRxiv preprint doi: https://doi.org/10.1101/2021.04.17.21255471; this version posted April 20, 2021. The copyright holder for this preprint (which was not certified by peer review) is the author/funder, who has granted medRxiv a license to display the preprint in perpetuity. All rights reserved. No reuse allowed without permission.

960

961

962

963

964

965

966

967

968

969

970

971

972

973

974

975

976

977

978

979

980

981

982

983

984

985

986

987

988

989

990

991

992

993

994

995

996

997

998

999

1000

1001

1002

1003

1004

57. Whang, A., Nagpal, R. \& Yadav, H. Bi-directional drug-microbiome interactions of anti-diabetics. EBioMedicine 39, 591-602 (2019).

58. Voight, B.F. et al. The metabochip, a custom genotyping array for genetic studies of metabolic, cardiovascular, and anthropometric traits. PLoS Genet 8, e1002793 (2012).

59. Li, Y., Willer, C., Sanna, S. \& Abecasis, G. Genotype imputation. Annu Rev Genomics Hum Genet 10, 387-406 (2009).

60. Marchini, J., Howie, B., Myers, S., McVean, G. \& Donnelly, P. A new multipoint method for genome-wide association studies by imputation of genotypes. Nat Genet 39, 906-13 (2007).

61. Fuchsberger, C., Abecasis, G.R. \& Hinds, D.A. minimac2: faster genotype imputation. Bioinformatics 31, 782-4 (2015).

62. Loh, P.R., Kichaev, G., Gazal, S., Schoech, A.P. \& Price, A.L. Mixed-model association for biobank-scale datasets. Nat Genet 50, 906-908 (2018).

63. Loh, P.R. et al. Efficient Bayesian mixed-model analysis increases association power in large cohorts. Nat Genet 47, 284-90 (2015).

64. Genomes Project, C. et al. A global reference for human genetic variation. Nature 526, 68-74 (2015).

65. Rueger, S., McDaid, A. \& Kutalik, Z. Evaluation and application of summary statistic imputation to discover new height-associated loci. PLoS Genet 14, e1007371 (2018).

66. Willer, C.J., Li, Y. \& Abecasis, G.R. METAL: fast and efficient meta-analysis of genomewide association scans. Bioinformatics 26, 2190-1 (2010).

67. Magi, R. \& Morris, A.P. GWAMA: software for genome-wide association metaanalysis. BMC Bioinformatics 11, 288 (2010).

68. Chang, C.C. et al. Second-generation PLINK: rising to the challenge of larger and richer datasets. Gigascience 4, 7 (2015).

69. Yang, J. et al. Conditional and joint multiple-SNP analysis of GWAS summary statistics identifies additional variants influencing complex traits. Nat Genet 44, 369-75, S1-3 (2012).

70. Fang, Z. et al. The Influence of Peptide Context on Signaling and Trafficking of Glucagon-like Peptide-1 Receptor Biased Agonists. ACS Pharmacol Trans/ Sci 3, 345360 (2020).

71. Fang, Z. et al. Ligand-Specific Factors Influencing GLP-1 Receptor Post-Endocytic Trafficking and Degradation in Pancreatic Beta Cells. Int J Mol Sci 21(2020).

72. Ward, R.J., Alvarez-Curto, E. \& Milligan, G. Using the Flp-In T-Rex system to regulate GPCR expression. Methods Mol Biol 746, 21-37 (2011).

73. Peng, T. et al. A BaSiC tool for background and shading correction of optical microscopy images. Nat Commun 8, 14836 (2017).

74. Jaccard, N. et al. Automated method for the rapid and precise estimation of adherent cell culture characteristics from phase contrast microscopy images. Biotechnol Bioeng 111, 504-17 (2014).

75. Kenakin, T. A Scale of Agonism and Allosteric Modulation for Assessment of Selectivity, Bias, and Receptor Mutation. Mol Pharmacol 92, 414-424 (2017).

76. Harvey, M.J., Giupponi, G. \& Fabritiis, G.D. ACEMD: Accelerating Biomolecular Dynamics in the Microsecond Time Scale. J Chem Theory Comput 5, 1632-9 (2009). 
medRxiv preprint doi: https://doi.org/10.1101/2021.04.17.21255471; this version posted April 20, 2021. The copyright holder for this preprint (which was not certified by peer review) is the author/funder, who has granted medRxiv a license to display the preprint in perpetuity. All rights reserved. No reuse allowed without permission.

1005

1006

1007

1008

1009

1010

1011

1012

1013

1014

1015

1016

1017

1018

1019

1020

1021

1022

1023

1024

1025

1026

1027

1028

1029

1030

1031

1032

1033

1034

1035

1036

1037

1038

1039

1040

1041

1042

1043

1044

1045

1046

1047

1048

1049

1050

1051

77. Cuzzolin, A., Deganutti, G., Salmaso, V., Sturlese, M. \& Moro, S. AquaMMapS: An Alternative Tool to Monitor the Role of Water Molecules During Protein-Ligand Association. ChemMedChem 13, 522-531 (2018).

78. Wakefield, J. A Bayesian measure of the probability of false discovery in genetic epidemiology studies. Am J Hum Genet 81, 208-27 (2007).

79. Pers, T.H., Timshel, P. \& Hirschhorn, J.N. SNPsnap: a Web-based tool for identification and annotation of matched SNPs. Bioinformatics 31, 418-20 (2015).

80. Genomes Project, C. et al. A map of human genome variation from population-scale sequencing. Nature 467, 1061-73 (2010).

81. Tabula Muris, C. et al. Single-cell transcriptomics of 20 mouse organs creates a Tabula Muris. Nature 562, 367-372 (2018).

82. Timshel, P.N., Thompson, J.J. \& Pers, T.H. Mapping heritability of obesity by brain cell types. bioRxiv, 2020.01.27.920033 (2020).

83. Barbeira, A.N. et al. Exploring the phenotypic consequences of tissue specific gene expression variation inferred from GWAS summary statistics. Nat Commun 9, 1825 (2018).

84. Gamazon, E.R. et al. A gene-based association method for mapping traits using reference transcriptome data. Nat Genet 47, 1091-8 (2015).

85. Delaneau, O., Marchini, J., Genomes Project, C. \& Genomes Project, C. Integrating sequence and array data to create an improved 1000 Genomes Project haplotype reference panel. Nat Commun 5, 3934 (2014).

86. lotchkova, V. et al. Discovery and refinement of genetic loci associated with cardiometabolic risk using dense imputation maps. Nat Genet 48, 1303-1312 (2016).

87. Almgren, P. et al. Genetic determinants of circulating GIP and GLP-1 concentrations. JCl Insight 2(2017).

88. Dobbyn, A. et al. Landscape of Conditional eQTL in Dorsolateral Prefrontal Cortex and Co-localization with Schizophrenia GWAS. Am J Hum Genet 102, 1169-1184 (2018).

89. Sharapov, S. et al. Genome-wide association summary statistics for human blood plasma glycome. (Zenodo, 2018).

90. Finucane, H.K. et al. Partitioning heritability by functional annotation using genomewide association summary statistics. Nat Genet 47, 1228-35 (2015).

91. Zheng, J. et al. LD Hub: a centralized database and web interface to perform LD score regression that maximizes the potential of summary level GWAS data for SNP heritability and genetic correlation analysis. Bioinformatics 33, 272-279 (2017).

92. Fedko, I.O. et al. Genetics of fasting indices of glucose homeostasis using GWIS unravels tight relationships with inflammatory markers. bioRxiv, 496802 (2018).

93. Shrine, N. et al. New genetic signals for lung function highlight pathways and chronic obstructive pulmonary disease associations across multiple ancestries. Nat Genet $\mathbf{5 1}$, 481-493 (2019).

94. Hemani, G. et al. The MR-Base platform supports systematic causal inference across the human phenome. Elife 7(2018).

95. Burgess, S. et al. Guidelines for performing Mendelian randomization investigations. Wellcome Open Res 4, 186 (2019).

96. Bowden, J., Davey Smith, G. \& Burgess, S. Mendelian randomization with invalid instruments: effect estimation and bias detection through Egger regression. Int J Epidemiol 44, 512-25 (2015). 
medRxiv preprint doi: https://doi.org/10.1101/2021.04.17.21255471; this version posted April 20, 2021. The copyright holder for this preprint (which was not certified by peer review) is the author/funder, who has granted medRxiv a license to display the preprint in perpetuity.

1052

1053

1054

1055

1056

1057

1058

1059

1060

1061

1062

1063

1064

1065

1066

1067

1068

1069

1070

1071

1072

1073

1074

1075

1076

1077
97. Mahajan, A. et al. Fine-mapping type 2 diabetes loci to single-variant resolution using high-density imputation and islet-specific epigenome maps. Nat Genet 50, 1505-1513 (2018).

98. Choi, S.W. \& O'Reilly, P.F. PRSice-2: Polygenic Risk Score software for biobank-scale data. Gigascience 8(2019).

\section{Acknowledgements}

\section{Airwave}

The Airwave Health Monitoring Study was funded by the UK Home Office (780- TETRA, 20032018) and is currently funded by the MRC and ESRC (MR/R023484/1) with additional funding from the NIHR Imperial College Biomedical Research Centre (BRC) in collaboration with Imperial College NHS Healthcare Trust. We thank all Airwave participants for their contribution to the study.

Personal support: Paul Elliott acknowledges support from the MRC and PHE (MR/L01341X/1, 812 2014-2019) and currently from the MRC for the MRC Centre for Environment and Health 813 (MR/S019669/1). Paul Elliott and Ioanna Tzoulaki are supported by the UK Dementia Research Institute which 814 receives funding from UK DRI Ltd funded by the UK Medical Research Council, Alzheimer's 815 Society and Alzheimer's Research UK. Paul Elliott is associate director of the Health Data 816 Research UK London funded by a consortium led by the UK Medical Research Council.

\section{BRIGHT}

This work was funded by the Medical Research Council of Great Britain (grant number: G9521010D). The BRIGHT study is extremely grateful to all the patients who participated in the study and the BRIGHT nursing team. This work formed part of the research themes 
medRxiv preprint doi: https://doi.org/10.1101/2021.04.17.21255471; this version posted April 20, 2021. The copyright holder for this preprint (which was not certified by peer review) is the author/funder, who has granted medRxiv a license to display the preprint in perpetuity. All rights reserved. No reuse allowed without permission.

1078

1079

1080

1081

1082

1083

1084

1085

1086

1087

1088

1089

1090

1091

1092

1093

1094

1095

1096

1097

1098

1099

1100

contributing to the translational research portfolio for the NIHR Barts Cardiovascular Biomedical Research Centre. The funders had no role in study design, data collection and analysis.

\section{deCODE}

We thank participants in deCODE genetic studies whose contribution made this work possible.

\section{EMIL}

EMIL-Cohort, a population-based cohort; the study was approved by the ethical committee of the Chamber of Physicians Baden-Württemberg in the year 2002 (Registration Number 133-02; dates 05.09.2002 and 24.09.2002). We thank Silke Rosinger, Simone Claudi-Boehm, Rosina Sing, Sabine Schilling and Angelika Kurkhaus for technical support.

\section{EPIC-Norfolk}

The EPIC-Norfolk study (https://doi.org/10.22025/2019.10.105.00004) has received funding from the Medical Research Council (MR/N003284/1 and MC-UU_12015/1) and Cancer Research UK (C864/A14136). The genetics work in the EPIC-Norfolk study was funded by the Medical Research Council (MC_PC_13048). We are grateful to all the participants who have been part of the project and to the many members of the study teams at the University of Cambridge who have enabled this research.

\section{FINRISK87}


medRxiv preprint doi: https://doi.org/10.1101/2021.04.17.21255471; this version posted April 20, 2021. The copyright holder for this preprint (which was not certified by peer review) is the author/funder, who has granted medRxiv a license to display the preprint in perpetuity. All rights reserved. No reuse allowed without permission.

1101 Support for FUSION was provided by NIH grants R01-DK062370 (to M.B.), R01-DK072193 (to

1102 K.L.M.), and intramural project number 1Z01-HG000024 (to F.S.C.). Genome-wide genotyping 1103 was conducted by the Johns Hopkins University Genetic Resources Core Facility SNP Center 1104 at the Center for Inherited Disease Research (CIDR), with support from CIDR NIH contract no.

1105 N01-HG-65403.

1106

1107 Framingham Heart Study

1108 Also supported by National Institute for Diabetes and Digestive and Kidney Diseases (NIDDK) 1109 U01/UM1 DK078616 to Dr. Meigs

\section{HUNT2/Tromson}

1112 The Nord-Trøndelag Health Study (the HUNT study) is a collaboration between HUNT

1113 Research Centre (Faculty of Medicine, Norwegian University of Science and Technology

1114 NTNU), Nord-Trøndelag County Council, Central Norway Health Authority, and the Norwegian

1115 Institute of Public Health. University of Troms $\varnothing$, Norwegian Research Council (project number 1116 185764).

1119 We thank all EPIC participants and staff and the InterAct Consortium members for their 1120 contributions to the study. The InterAct project received funding from the European Union 1121 (Integrated Project LSHM-CT-2006-037197 in the Framework Programme 6 of the European

1122 Community). We thank staff from the technical, field epidemiology and data teams of the 1123 Medical Research Council Epidemiology Unit in Cambridge, UK, for carrying out sample 1124 preparation, DNA provision and quality control, genotyping and data handling work. 
medRxiv preprint doi: https://doi.org/10.1101/2021.04.17.21255471; this version posted April 20, 2021. The copyright holder for this preprint (which was not certified by peer review) is the author/funder, who has granted medRxiv a license to display the preprint in perpetuity.

KORA F3

1127 The KORA research platform (KORA, Cooperative Research in the Region of Augsburg) was

1128 initiated and financed by the Helmholtz Zentrum München-German Research Center for

1129 Environment and Health, which is funded by the German Federal Ministry of Education and

1130 Research and by the state of Bavaria. Furthermore, part of this work was supported by the

1131 German National Genome Research Network (NGFN) and the Munich Center of Health

1132 Sciences (MC Health) as part of LMUinnovativ.

1133

1134

Brisbane Adolescent Twin Study / SSAGA-NAG adult cohort

1135 Genotyping and phenotyping were supported by the Australian National Health and Medical

1136 Research Council (389891, 389892, 496739), the EU 5th Framework Programme

1137 GenomEUtwin Project (QLG2-CT-2002-01254) and the U.S. National Institutes of Health

1138 (AA07535, AA13320, AA13321, AA13326, AA14041, DA12854). B.B. and G.W.M. are

1139 supported by National Health and Medical Research Council (NHMRC) Fellowship Schemes.

1140 Participants gave informed consent and the studies were approved by appropriate

1141 institutional review boards.

PPP-Botnia/Malmö Diet Cancer

1144 Personal support: Emma Ahlqvist was funded by grants from the Swedish Research Council 1145 (2017-02688, 2020-02191). 
medRxiv preprint doi: https://doi.org/10.1101/2021.04.17.21255471; this version posted April 20, 2021. The copyright holder for this preprint (which was not certified by peer review) is the author/funder, who has granted medRxiv a license to display the preprint in perpetuity. All rights reserved. No reuse allowed without permission.

1148

1149

1150

1151

1152

1153

1154

1155

1156

1157

1158

1159

1160

1161

1162

1163

1164

1165

1166

1167

1168

1169

1170

1171

PROCARDIS was supported by the European Community Sixth Framework Program (LSHM-

CT- 2007-037273), AstraZeneca, the British Heart Foundation, the Wellcome Trust (Contract No. 075491/Z/04), the Swedish Research Council, the Knut and Alice Wallenberg Foundation, the Swedish Heart-Lung Foundation, the Torsten and Ragnar Söderberg Foundation, the Strategic Cardiovascular and Diabetes Programs of Karolinska Institutet and Stockholm County Council, the Foundation for Strategic Research and the Stockholm County Council. Ethical permission was granted by the local ethical board for each centre.

Personal support: Anuj Goel has received support from the BHF, European Commission [LSHM-CT- 2007-037273, HEALTH-F2-2013-601456] and TriPartite Immunometabolism Consortium [TrIC]- NovoNordisk Foundation [NNF15CC0018486]. Hugh Watkins has received support from Wellcome Trust core awards (090532/Z/09/Z, 203141/Z/16/Z) and is member of the Oxford BHF Centre for Research Excellence (RE/13/1/30181). Rona J Strawbridge is supported by a UKRI Innovation-HDR-UK Fellowship (MR/S003061/1).

\section{Rotterdam Study}

The generation and management of GWAS genotype data for the Rotterdam Study is supported by the Netherlands Organisation of Scientific Research NWO Investments (nr. 175.010.2005.011, 911-03-012). This study is funded by the Research Institute for Diseases in the Elderly (014-93-015; RIDE2), the Netherlands Genomics Initiative (NGI)/Netherlands Organisation for Scientific Research (NWO) project nr. 050-060-810. We thank Pascal Arp, Mila Jhamai, Marijn Verkerk, Lizbeth Herrera and Marjolein Peters for their help in creating the GWAS database, and Karol Estrada and Maksim V. Struchalin for their support in creation and analysis of imputed data. The Rotterdam Study is funded by Erasmus Medical Center and Erasmus University, Rotterdam, Netherlands Organization for the Health Research and 
medRxiv preprint doi: https://doi.org/10.1101/2021.04.17.21255471; this version posted April 20, 2021. The copyright holder for this preprint (which was not certified by peer review) is the author/funder, who has granted medRxiv a license to display the preprint in perpetuity. All rights reserved. No reuse allowed without permission.

1172 Development (ZonMw), the Research Institute for Diseases in the Elderly (RIDE), the Ministry

1173 of Education, Culture and Science, the Ministry for Health, Welfare and Sports, the European

1174 Commission (DG XII), and the Municipality of Rotterdam. The authors are grateful to the study

1175 participants, the staff from the Rotterdam Study and the participating general practitioners

1176 and pharmacists.

1177

1178 The Section of Endocrinology and Investigative Medicine is funded by grants from the MRC,

1179 BBSRC, NIHR, and is supported by the NIHR Biomedical Research Centre Funding Scheme. The

1180 views expressed are those of the author(s) and not necessarily those of the any of the funders,

1181 the NHS, the NIHR or the Department of Health.

1182

1183

\section{UK Biobank}

1184 We thank UK Biobank for data availability, project number 37685.

1185 Personal support: Marika A Kaakinen, Anna Ulrich, Zhanna Balkhiyarova and Inga Prokopenko

1186 are in part funded by the European Union's Horizon 2020 research and innovation

1187 programme LONGITOOLS, H2020-SC1-2019-874739. Marika A Kaakinen is also funded by the

1188 European Foundation for the Study of Diabetes (EFSD) Albert Renold Travel Fellowship.

Vanderbilt

1191 The samples and/or dataset(s) used for the analyses described were obtained from Vanderbilt

1192 University Medical Center's BioVU which is supported by numerous sources: institutional

1193 funding, private agencies, and federal grants. These include the NIH funded Shared

1194 Instrumentation Grant S100D017985 and S10RR025141; and CTSA grants UL1TR002243,

1195 UL1TR000445, and UL1RR024975. Genomic data are also supported by investigator-led 
medRxiv preprint doi: https://doi.org/10.1101/2021.04.17.21255471; this version posted April 20, 2021. The copyright holder for this preprint (which was not certified by peer review) is the author/funder, who has granted medRxiv a license to display the preprint in perpetuity. All rights reserved. No reuse allowed without permission.

1196

1197

1198

1199

1200

1201

1202

1203

1204

1205

1206

1207

1208

1209

1210

1211

1212 England.

1213

1214

1215

1216

1217

1218

projects that include U01HG004798, R01NS032830, RC2GM092618, P50GM115305, U01HG006378, U19HL065962, R01HD074711; and additional funding sources listed at https://victr.vumc.org/biovu-funding/".

Personal support: NIH Grants R01 HL146588 and R01 HL146588-01S1.

\section{Individual acknowledgements}

Alejandra Tomas was supported by MRC project grant MR/R010676/1 and grants from Diabetes UK and the European Federation for the Study of Diabetes.

Alessia David is funded by Wellcome Trust grant 104955/Z/14/Z.

Ben Jones is supported by an Imperial Post-CCT Post-Doctoral Fellowship, MRC project grant MR/R010676/1, and grants from the European Federation for the Study of Diabetes, Academy of Medical Sciences, Imperial NIHR Biomedical Research Centre, Engineering and Physical Sciences Research Council, Society for Endocrinology and British Society for Neuroendocrinology.

Christopher Reynolds is a Royal Society Industry Fellow.

Inês Barroso was funded by an "Expanding excellence in England" award from Research Inga Prokopenko is funded by the World Cancer Research Fund (WCRF UK) and World Cancer Research Fund International (2017/1641), the Wellcome Trust (WT205915), the European Union's Horizon 2020 research and innovation programme (DYNAhealth, project number 633595) the LONGITOOLS, H2020-SC1-2019-874739 and the Royal Society (IEC\R2\181075). Mark McCarthy was a Wellcome Investigator and an NIHR Senior Investigator (Niddk. U01DK105535, Wellcome: 090532, 098381, 106130, 203141, 212259). 
medRxiv preprint doi: https://doi.org/10.1101/2021.04.17.21255471; this version posted April 20, 2021. The copyright holder for this preprint (which was not certified by peer review) is the author/funder, who has granted medRxiv a license to display the preprint in perpetuity. All rights reserved. No reuse allowed without permission.

1219

1220

1221

1222

1223

1224

1225

1226

1227

1228

1229

1230

1231

1232

1233

1234

1235

1236

1237

1238

1239

1240

1241

1242

1243

Patrick M Sexton and Denise Wootten: The work was supported by NHMRC Ideas \#1184726 and NHMRC program grant \#1150083. Patrick M Sexton is a NHMRC Senior Principal Research Fellow (\#1154434) and Denise Wootten is an NHMRC Senior Research Fellow (\#1155302).

Vasiliki Lagou was supported by a fellowship from the Research Foundation-Flanders (FWO).

Victoria Salem is the recipient of a Diabetes UK Harry Keen Clinician Scientist Fellowship.

Sharapov Sodbo was supported by a grant from the Russian Science Foundation

(RSF) No. 19-15-00115.

Tricia M Tan acknowledges support from the National Institute for Health Research (NIHR) Imperial Biomedical Research Centre (BRC) Funding Scheme.

\section{Author contributions}

First author: V.L., L.J., A.U., Central analysis and writing group: V.L., L.J., A.U., L.Z., K.G., Z.B., A.F., L.M., Additional analyses junior lead: S.C., P.T., S.S., A.David, R.M., R.R., E.Ahlqvist, T.M.T., A.T., V.Salem, GWAS cohort analyst: G.T., H.G., E.E., B.B., R.S., A.I., J.Z., S.M.W., T.J., C.G., H.G., C.M., M.M., R.J.S., A.G., D.R., J.D., Y.S.A., M.A.K., Metabochip cohort analyst: E.Albrecht, A.U.J., H.M.S., Cohort sample collection, genotyping, phenotyping or additional analysis: I.R.C., F.E., V.Steinthorsdottir, A.G.U., P.B.M., M.J.B., S.J., O.H., B.T., K.H., T.W., K.L.M., Metabochip cohort PI: W.Kratzer, H.M., W.Koenig, B.O.B., GWAS cohort PI: J.T., M.B., J.C.F., A.Hamsten, H.Watkins, I.N., H.Wichmann, M.J.C., K.K., C.v.D., A.Hofman, N.J.W., C.L., J.B.W., N.G.M., G.M., I.T., P.E., U.T., K.S., E.L.B., J.B.M., Additional analyses senior: P.M.S., D.W., L.G., G.D., A.Demirkan, T.H.P., C.A.R., Other senior author (analysis and writing group): Y.S.A., Other senior author (writing): I.B., C.S., M.I.M., P.F., J.D., J.B.M., Senior author: M.A.K., B.J., I.P.

\section{Competing interests}

Alejandra Tomas has received grant funding from Sun Pharmaceuticals. 
medRxiv preprint doi: https://doi.org/10.1101/2021.04.17.21255471; this version posted April 20, 2021. The copyright holder for this preprint (which was not certified by peer review) is the author/funder, who has granted medRxiv a license to display the preprint in perpetuity.

Ivan R Corrêa, Jr is an employee of New England Biolabs, Inc., a manufacturer and vendor of

1245 reagents for life science research.

1246 Mark J Caulfield is Chief Scientist for Genomics England, a UK Government company.

1247 The views expressed in this article are those of the author(s) and not necessarily those of the

1248 NHS, the NIHR, or the Department of Health. Mark McCarthy has served on advisory panels

1249 for Pfizer, NovoNordisk and Zoe Global, has received honoraria from Merck, Pfizer, Novo

1250 Nordisk and Eli Lilly, and research funding from Abbvie, Astra Zeneca, Boehringer Ingelheim,

1251 Eli Lilly, Janssen, Merck, NovoNordisk, Pfizer, Roche, Sanofi Aventis, Servier, and Takeda. As

1252 of June 2019, MMcC is an employee of Genentech, and a holder of Roche stock.

1253 Patrick M Sexton receives grant funding from Laboratoires Servier.

1254 Toby Johnson is now a GSK employee.

1255

Yurii S Aulchenko is owner of Maatschap PolyOmica and PolyKnomics BV, private organizations providing services, research and development in the field of computational and statistical, quantitative and computational (gen)omics.

1258 
medRxiv preprint doi: https://doi.org/10.1101/2021.04.17.21255471; this version posted April 20, 2021. The copyright holder for this preprint (which was not certified by peer review) is the author/funder, who has granted medRxiv a license to display the preprint in perpetuity. All rights reserved. No reuse allowed without permission.

\section{Tables}

1269 Table 1. Novel loci for glycaemic traits discovered through i) a GWAS meta-analysis of RG 1270 levels in up to $\mathbf{4 7 9 , 4 8 2}$ Europeans without diabetes, and ii) a trans-ethnic meta-analysis of 1271 up to 496,036 Europeans and individuals of other ancestries (Black, Indian, Pakistani, 1272 Chinese) in UKBB. Loci showing sex-dimorphic effects on glycaemic trait levels for the first 1273 time are also shown.

1274

\begin{tabular}{|c|c|c|c|c|c|c|c|c|c|c|c|}
\hline Signal & Nearest gene(s) & Lead variant & Chr & Position & Type & $\begin{array}{c}\text { Alleles } \\
\text { (effect/ } \\
\text { other) }\end{array}$ & EAF & Effect (SE) & $P$-value & $P$ het & $\mathbf{N}$ \\
\hline European & KDM4A & rs3791033 & 1 & $44,134,077$ & primary & $\mathrm{T} / \mathrm{C}$ & 0.68 & $\begin{array}{c}-0.0018 \\
(0.00030) \\
\end{array}$ & $4.5 \times 10^{-9}$ & 0.59 & 476,655 \\
\hline European & FAM46C & rs1966228 & 1 & $118,144,332$ & primary & $A / G$ & 0.74 & $\begin{array}{c}0.0032 \\
(0.00030) \\
\end{array}$ & $5.8 \times 10^{-22}$ & 0.13 & 472,798 \\
\hline $\begin{array}{c}\text { European, } \\
\text { nonsyn }\end{array}$ & EDEM3 & rs78444298 & 1 & $184,672,098$ & primary & $A / G$ & 0.019 & $\begin{array}{c}0.0073 \\
(0.0011) \\
\end{array}$ & $1.5 \times 10^{-11}$ & 0.61 & 439,856 \\
\hline European & ACVR1C & rs146418816 & 2 & $158,432,811$ & primary & $A / G$ & 0.057 & $\begin{array}{c}-0.0034 \\
(0.00060) \\
\end{array}$ & $5.6 \times 10^{-8}$ & 0.055 & 475,174 \\
\hline European & ACVR1C & rs 2509903 & 2 & $158,514,510$ & secondary & $\mathrm{T} / \mathrm{C}$ & 0.14 & $\begin{array}{c}0.0022 \\
(0.00040) \\
\end{array}$ & $6.7 \times 10^{-8}$ & 0.14 & 478,582 \\
\hline European & RBMS1 & rs12692596 & 2 & $161,265,910$ & primary & $T / C$ & 0.37 & $\begin{array}{c}0.0018 \\
(0.00030)\end{array}$ & $1.3 \times 10^{-9}$ & 0.84 & 478,570 \\
\hline European & G6PC2 & rs143869345 & 2 & $169,708,322$ & secondary & $A / G$ & 0.98 & $\begin{array}{c}-0.0152 \\
(0.0012) \\
\end{array}$ & $1.7 \times 10^{-37}$ & 1.00 & 401,810 \\
\hline $\begin{array}{c}\text { European, } \\
\text { nonsyn }\end{array}$ & NEUROD 1 & rs8192556 & 2 & $182,542,998$ & primary & $T / G$ & 0.024 & $\begin{array}{c}0.0053 \\
(0.00090)\end{array}$ & $2.8 \times 10^{-8}$ & 0.50 & 439,856 \\
\hline European & CACNA2D3 & rs34222465 & 3 & $55,123,055$ & primary & $A / G$ & 0.56 & $\begin{array}{c}-0.0019 \\
(0.00030) \\
\end{array}$ & $5.5 \times 10^{-10}$ & 0.052 & 439,856 \\
\hline European & MBNL1 & rs4679997 & 3 & $152,396,466$ & secondary & $\mathrm{C} / \mathrm{G}$ & 0.33 & $\begin{array}{c}0.0017 \\
(0.00030) \\
\end{array}$ & $9.3 \times 10^{-8}$ & 0.28 & 473,926 \\
\hline European & MBNL1 & rs78482374 & 3 & $152,492,522$ & secondary & $\mathrm{A} / \mathrm{T}$ & 0.037 & $\begin{array}{c}-0.0042 \\
(0.00080)\end{array}$ & $6.7 \times 10^{-8}$ & 0.22 & 455,510 \\
\hline European & TRIM59,KPNA4 & rs56394279 & 3 & $160,171,092$ & primary & $\mathrm{T} / \mathrm{C}$ & 0.52 & $\begin{array}{c}-0.0018 \\
(0.00030) \\
\end{array}$ & $1.2 \times 10^{-9}$ & 0.068 & 474,089 \\
\hline European & MECOM & rs73174306 & 3 & $169,194,244$ & primary & $A / T$ & 0.96 & $\begin{array}{c}-0.0057 \\
(0.00070)\end{array}$ & $1.4 \times 10^{-14}$ & 0.095 & 432,212 \\
\hline European & LCORL & rs75631642 & 4 & $18,049,216$ & secondary & $\mathrm{T} / \mathrm{C}$ & 0.78 & $\begin{array}{c}-0.0017 \\
(0.00040) \\
\end{array}$ & $2.1 \times 10^{-6}$ & 0.13 & 466,061 \\
\hline European & LCORL & rs6840504 & 4 & $18,205,102$ & primary & $\mathrm{T} / \mathrm{C}$ & 0.45 & $\begin{array}{c}0.0018 \\
(0.00030)\end{array}$ & $1.2 \times 10^{-9}$ & 0.15 & 475,423 \\
\hline European & ADRB2 & rs71584073 & 5 & $148,149,418$ & primary & $T / C$ & 0.93 & $\begin{array}{c}0.0035 \\
(0.00060) \\
\end{array}$ & $3.3 \times 10^{-10}$ & 0.44 & 439,856 \\
\hline European & SYNGAP1 & rs9461856 & 6 & $33,395,199$ & primary & $A / G$ & 0.48 & $\begin{array}{c}-0.00030 \\
(0.00030) \\
\end{array}$ & 0.33 & 0.091 & 457,070 \\
\hline European & ITPR3 & rs1830873 & 6 & $33,620,397$ & primary & $\mathrm{C} / \mathrm{G}$ & 0.57 & $\begin{array}{c}0.00070 \\
(0.00030) \\
\end{array}$ & 0.021 & 0.87 & 452,301 \\
\hline European & $A R M C 2, S E S N 1$ & rs118126621 & 6 & $109,304,170$ & primary & $A / G$ & 0.025 & $\begin{array}{c}0.0039 \\
(0.0010) \\
\end{array}$ & $5.0 \times 10^{-5}$ & 0.049 & 432,212 \\
\hline European & $P O P 7, E P O$ & rs534043 & 7 & $100,312,724$ & primary & $A / G$ & 0.11 & $\begin{array}{c}-0.0031 \\
(0.00050)\end{array}$ & $1.7 \times 10^{-11}$ & 0.37 & 475,631 \\
\hline European & PRKAR2B & rs3801969 & 7 & $106,711,492$ & primary & $T / G$ & 0.43 & $\begin{array}{c}0.0016 \\
(0.00030) \\
\end{array}$ & $2.2 \times 10^{-8}$ & 0.22 & 478,580 \\
\hline European & $A 1 C F$ & rs61856594 & 10 & $52,637,925$ & primary & $A / G$ & 0.71 & $\begin{array}{c}0.0022 \\
(0.00030)\end{array}$ & $1.6 \times 10^{-11}$ & 0.58 & 473,354 \\
\hline European & PRKG1 & rs4415704 & 10 & $53,561,613$ & primary & $\mathrm{T} / \mathrm{C}$ & 0.42 & $\begin{array}{c}-0.0016 \\
(0.00030) \\
\end{array}$ & $5.6 \times 10^{-8}$ & 0.82 & 474,069 \\
\hline European & LMO1 & rs9667977 & 11 & $8,541,291$ & secondary & $\mathrm{T} / \mathrm{C}$ & 0.46 & $\begin{array}{c}-0.0013 \\
(0.00030) \\
\end{array}$ & $4.5 \times 10^{-6}$ & 0.71 & 457,903 \\
\hline European & USP47 & rs34718245 & 11 & $11,863,080$ & primary & $A / G$ & 0.15 & $\begin{array}{c}-0.0023 \\
(0.00040)\end{array}$ & $4.3 \times 10^{-8}$ & 0.63 & 470,144 \\
\hline European & $P D E 3 B$ & rs141521721 & 11 & $14,763,828$ & primary & $\mathrm{A} / \mathrm{C}$ & 0.023 & $\begin{array}{c}0.0050 \\
(0.0010) \\
\end{array}$ & $1.8 \times 10^{-7}$ & 0.0059 & 439,856 \\
\hline
\end{tabular}


medRxiv preprint doi: https://doi.org/10.1101/2021.04.17.21255471; this version posted April 20, 2021. The copyright holder for this preprint (which was not certified by peer review) is the author/funder, who has granted medRxiv a license to display the preprint in perpetuity. All rights reserved. No reuse allowed without permission.

\begin{tabular}{|c|c|c|c|c|c|c|c|c|c|c|c|}
\hline European & PDHX & rs75479466 & 11 & $34,961,066$ & primary & $A / G$ & 0.083 & $\begin{array}{c}0.0029 \\
(0.00050)\end{array}$ & $2.1 \times 10^{-8}$ & 0.29 & 472,109 \\
\hline European & OR4A5 & rs72913090 & 11 & $50,653,357$ & primary & $\mathrm{A} / \mathrm{C}$ & 0.92 & $\begin{array}{c}0.0031 \\
(0.00050)\end{array}$ & $1.0 \times 10^{-8}$ & 0.13 & 418,793 \\
\hline \multirow[t]{2}{*}{ European } & TRIM48 & rs150587121 & 11 & $55,036,391$ & primary & $\mathrm{T} / \mathrm{C}$ & 0.91 & $\begin{array}{c}0.0029 \\
(0.00050)\end{array}$ & $7.7 \times 10^{-8}$ & 0.14 & 435,903 \\
\hline & OR8K3,OR8K1 & rs2170441 & 11 & $56,095,739$ & primary & $A / G$ & 0.076 & $\begin{array}{c}-0.0031 \\
(0.00060)\end{array}$ & $1.7 \times 10^{-8}$ & 0.28 & 422,873 \\
\hline European & SOX5 & rs12581677 & 12 & $24,060,732$ & primary & $A / G$ & 0.91 & $\begin{array}{c}0.0031 \\
(0.00050)\end{array}$ & $1.2 \times 10^{-9}$ & 0.036 & 477,019 \\
\hline European & MANSC4,KLHL42 & rs11049144 & 12 & $27,931,511$ & primary & $\mathrm{A} / \mathrm{C}$ & 0.22 & $\begin{array}{c}-0.0021 \\
(0.00040)\end{array}$ & $1.5 \times 10^{-9}$ & 0.010 & 455,032 \\
\hline European & MANSC4,KLHL42 & rs10492373 & 12 & $27,959,998$ & primary & $A / G$ & 0.19 & $\begin{array}{c}-0.0022 \\
(0.00040)\end{array}$ & $2.3 \times 10^{-9}$ & 0.0095 & 479,267 \\
\hline European & RNF6 & rs12874929 & 13 & $26,781,607$ & primary & $A / G$ & 0.77 & $\begin{array}{c}-0.0027 \\
(0.00030)\end{array}$ & $1.1 \times 10^{-14}$ & 0.97 & 476,730 \\
\hline European & $K L$ & rs488166 & 13 & $33,554,352$ & primary & $\mathrm{C} / \mathrm{G}$ & 0.18 & $\begin{array}{c}0.0042 \\
(0.00040)\end{array}$ & $3.0 \times 10^{-27}$ & 0.064 & 478,334 \\
\hline European & ZC3H13 & rs12429980 & 13 & $46,550,138$ & primary & $\mathrm{A} / \mathrm{C}$ & 0.30 & $\begin{array}{c}-0.0018 \\
(0.00030)\end{array}$ & $7.3 \times 10^{-9}$ & 0.40 & 474,764 \\
\hline European & SPRY2 & rs1359790 & 13 & $80,717,156$ & primary & $A / G$ & 0.28 & $\begin{array}{c}-0.0019 \\
(0.00030)\end{array}$ & $4.2 \times 10^{-9}$ & 0.0010 & 477,640 \\
\hline European & HECTD1,HEATR5A & rs727675 & 14 & $31,733,642$ & primary & $\mathrm{A} / \mathrm{G}$ & 0.57 & $\begin{array}{c}0.0017 \\
(0.00030)\end{array}$ & $7.5 \times 10^{-9}$ & 0.86 & 477,060 \\
\hline European & WARS & rs45617834 & 14 & $101,295,801$ & secondary & $\mathrm{C} / \mathrm{G}$ & 0.97 & $\begin{array}{c}0.0043 \\
(0.00090) \\
\end{array}$ & $1.2 \times 10^{-6}$ & 0.79 & 432,212 \\
\hline European & HERC1 & rs67507374 & 15 & $64,038,340$ & primary & $\mathrm{A} / \mathrm{T}$ & 0.30 & $\begin{array}{c}-0.0023 \\
(0.00030) \\
\end{array}$ & $4.3 \times 10^{-13}$ & 0.20 & 475,691 \\
\hline European & ITFG3, RAB11FIP3 & rs111811257 & 16 & 541,818 & secondary & $\mathrm{T} / \mathrm{C}$ & 0.040 & $\begin{array}{c}-0.0046 \\
(0.00070)\end{array}$ & $5.5 \times 10^{-10}$ & 0.76 & 432,212 \\
\hline European & TAOK1,ABHD15 & rs9894551 & 17 & $27,880,124$ & primary & $\mathrm{A} / \mathrm{T}$ & 0.17 & $\begin{array}{c}-0.0027 \\
(0.00040) \\
\end{array}$ & $5.2 \times 10^{-11}$ & 0.71 & 415,229 \\
\hline European & HNF1B & rs10908278 & 17 & $36,099,952$ & primary & $\mathrm{A} / \mathrm{T}$ & 0.52 & $\begin{array}{c}-0.0017 \\
(0.00030)\end{array}$ & $5.2 \times 10^{-9}$ & 0.0041 & 439,856 \\
\hline $\begin{array}{l}\text { European, } \\
\text { syn }\end{array}$ & NMT1 & rs2239923 & 17 & $43,176,804$ & primary & $\mathrm{T} / \mathrm{C}$ & 0.29 & $\begin{array}{c}0.0019 \\
(0.00030)\end{array}$ & $4.1 \times 10^{-9}$ & 0.62 & 478,582 \\
\hline \multirow[t]{2}{*}{$\begin{array}{c}\text { European, } \\
\text { nonsyn }\end{array}$} & WIPI1 & rs883541 & 17 & $66,449,122$ & primary & $A / G$ & 0.77 & $\begin{array}{c}-0.0024 \\
(0.00030) \\
\end{array}$ & $4.4 \times 10^{-12}$ & 0.24 & 477,006 \\
\hline & SKA1,MAPK4 & rs2957989 & 18 & $48,075,733$ & primary & $A / G$ & 0.82 & $\begin{array}{c}0.0021 \\
(0.00040)\end{array}$ & $2.2 \times 10^{-8}$ & 0.72 & 458,445 \\
\hline \multirow[t]{2}{*}{ European } & $R A L Y$ & rs6059497 & 20 & $32,446,960$ & primary & $\mathrm{C} / \mathrm{G}$ & 0.54 & $\begin{array}{c}-0.0017 \\
(0.00030)\end{array}$ & $9.2 \times 10^{-9}$ & 0.85 & 464,409 \\
\hline & HNF4A & rs2267850 & 20 & $43,524,963$ & primary & $\mathrm{T} / \mathrm{C}$ & 0.27 & $\begin{array}{l}-0.0019 \\
(0.0003) \\
\end{array}$ & $3.8 \times 10^{-9}$ & 0.92 & 458,445 \\
\hline European & TSHZ2 & rs2255805 & 20 & $51,627,634$ & primary & $\mathrm{T} / \mathrm{C}$ & 0.57 & $\begin{array}{c}-0.0018 \\
(0.00030)\end{array}$ & $5.5 \times 10^{-10}$ & 0.99 & 457,514 \\
\hline European & STX16-NPEPL1 & rs2296529 & 20 & $57,282,381$ & primary & $\mathrm{T} / \mathrm{C}$ & 0.77 & $\begin{array}{c}0.0020 \\
(0.0003)\end{array}$ & $5.5 \times 10^{-9}$ & 0.12 & 455,859 \\
\hline European & STX16-NPEPL1 & rs73129529 & 20 & $57,404,701$ & secondary & $C / G$ & 0.11 & $\begin{array}{c}0.0025 \\
(0.00050) \\
\end{array}$ & $1.0 \times 10^{-7}$ & 0.47 & 439,856 \\
\hline \multirow[t]{2}{*}{ European } & $E E F 1 A 2, P P D P F$ & rs6122466 & 20 & $62,139,177$ & primary & $\mathrm{A} / \mathrm{G}$ & 0.85 & $\begin{array}{c}-0.0027 \\
(0.00040)\end{array}$ & $1.6 \times 10^{-10}$ & 0.75 & 443,482 \\
\hline & MTMR3,HORMAD2 & rs5763882 & 22 & $30,597,426$ & primary & $A / G$ & 0.092 & $\begin{array}{c}-0.0028 \\
(0.00050)\end{array}$ & $2.9 \times 10^{-8}$ & 0.39 & 451,947 \\
\hline European & MTMR3,HORMAD2 & rs6006399 & 22 & $30,598,516$ & primary & $\mathrm{T} / \mathrm{G}$ & 0.88 & $\begin{array}{c}0.0025 \\
(0.00040)\end{array}$ & $2.4 \times 10^{-8}$ & 0.79 & 478,119 \\
\hline $\begin{array}{l}\text { European, } \\
\text { UKBB only }\end{array}$ & PEX7 & rs7756291 & 6 & 137235325 & primary & $\mathrm{T} / \mathrm{C}$ & 0.55 & $\begin{array}{l}-0.00080 \\
(0.00030)\end{array}$ & 0.0084 & 0.64 & 456,157 \\
\hline $\begin{array}{l}\text { European, } \\
\text { UKBB only }\end{array}$ & SLC38A4 & rs74832478 & 12 & 47193148 & primary & $\mathrm{T} / \mathrm{G}$ & 0.07 & $\begin{array}{c}0.0031 \\
(0.00060)\end{array}$ & $7.0 \times 10^{-8}$ & 0.03 & 476,132 \\
\hline $\begin{array}{l}\text { European, } \\
\text { UKBB only }\end{array}$ & INAFM2,C15orf52 & rs4143838 & 15 & 40622374 & primary & $\mathrm{T} / \mathrm{C}$ & 0.95 & $\begin{array}{c}-0.0036 \\
(0.00070)\end{array}$ & $2.3 \times 10^{-7}$ & 0.12 & 418,793 \\
\hline $\begin{array}{l}\text { European, } \\
\text { UKBB only }\end{array}$ & $A D C Y 9, S R L$ & rs2018506 & 16 & 4227922 & primary & $\mathrm{C} / \mathrm{G}$ & 0.85 & $\begin{array}{c}-0.0021 \\
(0.00040)\end{array}$ & $1.5 \times 10^{-7}$ & 0.45 & 461,733 \\
\hline $\begin{array}{l}\text { European, } \\
\text { UKBB only }\end{array}$ & ERN1 & rs57676627 & 17 & 62203128 & primary & $\mathrm{T} / \mathrm{C}$ & 0.15 & $\begin{array}{c}0.0022 \\
(0.00040)\end{array}$ & $4.0 \times 10^{-7}$ & 0.03 & 432,212 \\
\hline $\begin{array}{l}\text { European, } \\
\text { UKBB only }\end{array}$ & CELF5,NFIC & rs55740449 & 19 & 3334232 & primary & $\mathrm{T} / \mathrm{C}$ & 0.17 & $\begin{array}{c}0.0020 \\
(0.00040)\end{array}$ & $5.1 \times 10^{-7}$ & 0.79 & 439,856 \\
\hline
\end{tabular}


medRxiv preprint doi: https://doi.org/10.1101/2021.04.17.21255471; this version posted April 20, 2021. The copyright holder for this preprint (which was not certified by peer review) is the author/funder, who has granted medRxiv a license to display the preprint in perpetuity. All rights reserved. No reuse allowed without permission.

\begin{tabular}{|c|c|c|c|c|c|c|c|c|c|c|c|}
\hline $\begin{array}{l}\text { European, } \\
\text { UKBB only }\end{array}$ & RFX1 & rs2305780 & 19 & 14083761 & primary & $\mathrm{T} / \mathrm{C}$ & 0.54 & $\begin{array}{c}0.0015 \\
(0.00030)\end{array}$ & $2.5 \times 10^{-7}$ & 0.24 & 439,856 \\
\hline $\begin{array}{c}\text { Trans- } \\
\text { ethnic M-A }\end{array}$ & GATAD2B & rs10908526 & 1 & $153,883,169$ & primary & $\mathrm{C} / \mathrm{T}$ & 0.51 & $\begin{array}{c}0.0017 \\
(0.00030)\end{array}$ & $1.2 \times 10^{-8}$ & 0.35 & 479,064 \\
\hline $\begin{array}{c}\text { Trans- } \\
\text { ethnic M-A }\end{array}$ & RRNAD1 & rs3806415 & 1 & $156,698,265$ & primary & $\mathrm{C} / \mathrm{T}$ & 0.68 & $\begin{array}{c}-0.0017 \\
(0.00030)\end{array}$ & $4.8 \times 10^{-8}$ & 0.30 & 480,890 \\
\hline $\begin{array}{c}\text { Trans- } \\
\text { ethnic M-A }\end{array}$ & $P P P 1 C B, S P D Y A$ & rs111502507 & 2 & $29,009,180$ & primary & $A / G$ & 0.99 & $\begin{array}{c}0.0064 \\
(0.0011)\end{array}$ & $2.6 \times 10^{-8}$ & 0.97 & 439,427 \\
\hline $\begin{array}{c}\text { Trans- } \\
\text { ethnic M-A }\end{array}$ & MINPP1,PAPSS2 & rs11202473 & 10 & $89,378,838$ & primary & $\mathrm{G} / \mathrm{A}$ & 0.63 & $\begin{array}{c}-0.0017 \\
(0.00030)\end{array}$ & $1.2 \times 10^{-8}$ & 0.53 & 490,575 \\
\hline $\begin{array}{c}\text { Trans- } \\
\text { ethnic M-A }\end{array}$ & EPS8 & rs6488794 & 12 & $15,816,675$ & primary & $A / G$ & 0.030 & $\begin{array}{c}0.0048 \\
(0.00080)\end{array}$ & $1.4 \times 10^{-8}$ & 0.54 & 482,276 \\
\hline $\begin{array}{c}\text { Trans- } \\
\text { ethnic M-A }\end{array}$ & SLC38A4 & rs74832478 & 12 & $47,193,148$ & primary & $\mathrm{G} / \mathrm{T}$ & 0.93 & $\begin{array}{c}0.0033 \\
(0.00060)\end{array}$ & $7.7 \times 10^{-9}$ & 0.026 & 492,686 \\
\hline $\begin{array}{c}\text { Trans- } \\
\text { ethnic M-A }\end{array}$ & FOXN3 & rs12892260 & 14 & $89,580,986$ & secondary & $\mathrm{T} / \mathrm{C}$ & 0.94 & $\begin{array}{c}-0.0033 \\
(0.00060) \\
\end{array}$ & $1.5 \times 10^{-8}$ & 0.23 & 448,766 \\
\hline \multirow[t]{2}{*}{$\begin{array}{c}\text { Sex-dim: } \\
\text { men }\end{array}$} & PRDM16 & rs60330317 & 1 & $3,107,547$ & primary & $\mathrm{G} / \mathrm{A}$ & 0.82 & $\begin{array}{c}0.0011 \\
(0.00050)\end{array}$ & 0.021 & 0.0026 & 233,066 \\
\hline & & & & & & & 0.82 & $\begin{array}{c}0.0035 \\
(0.00060)\end{array}$ & $6.1 \times 10^{-9}$ & & 194,008 \\
\hline \multirow[t]{2}{*}{$\begin{array}{l}\text { Sex-dim: } \\
\text { women }\end{array}$} & SGIP1 & rs7532598 & 1 & $66,998,624$ & primary & C/A & 0.84 & $\begin{array}{c}-0.0029 \\
(0.00051)\end{array}$ & $1.2 \times 10^{-8}$ & 0.030 & 233,066 \\
\hline & & & & & & & 0.84 & $\begin{array}{c}-0.0012 \\
(0.00062)\end{array}$ & 0.053 & & 194,008 \\
\hline \multirow[t]{2}{*}{$\begin{array}{c}\text { Sex-dim: } \\
\text { men }\end{array}$} & THADA & rs149290349 & 2 & $43,451,957$ & $\begin{array}{l}\text { in LD with } \\
\text { primary }\end{array}$ & $\mathrm{G} / \mathrm{A}$ & 0.92 & $\begin{array}{c}0.0035 \\
(0.00074) \\
\end{array}$ & $2.2 \times 10^{-6}$ & $3.6 \times 10^{-4}$ & 233,066 \\
\hline & & & & & & & 0.92 & $\begin{array}{c}0.0076 \\
(0.00089)\end{array}$ & $1.0 \times 10^{-17}$ & & 194,008 \\
\hline \multirow[t]{2}{*}{$\begin{array}{l}\text { Sex-dim: } \\
\text { men }\end{array}$} & G6PC2 & rs13431652 & 2 & $169,753,415$ & $\begin{array}{c}\text { in LD with } \\
\text { primary }\end{array}$ & $\mathrm{T} / \mathrm{C}$ & 0.7 & $\begin{array}{c}0.016 \\
(0.00042)\end{array}$ & $1.0 \times 10^{-1374}$ & $5.6 \times 10^{-4}$ & 233,066 \\
\hline & & & & & & & 0.7 & $\begin{array}{c}0.018 \\
(0.00050)\end{array}$ & $3.4 \mathrm{E}-286$ & & 194,008 \\
\hline \multirow[t]{2}{*}{$\begin{array}{l}\text { Sex-dim: } \\
\text { men }\end{array}$} & TRIM59,KPNA4 & rs56394279 & 3 & $160,171,092$ & primary & $\mathrm{C} / \mathrm{T}$ & 0.49 & $\begin{array}{c}0.0012 \\
(0.00038)\end{array}$ & 0.0015 & 0.0075 & 233,066 \\
\hline & & & & & & & 0.49 & $\begin{array}{c}0.0028 \\
(0.00046)\end{array}$ & $8.7 \times 10^{-10}$ & & 194,008 \\
\hline \multirow[t]{2}{*}{$\begin{array}{l}\text { Sex-dim: } \\
\text { men }\end{array}$} & SOGA3,RSPO3 & rs2800734 & 6 & $127,417,035$ & primary & $\mathrm{G} / \mathrm{A}$ & 0.71 & $\begin{array}{c}0.0011 \\
(0.00042)\end{array}$ & 0.0077 & 0.0032 & 233,066 \\
\hline & & & & & & & 0.71 & $\begin{array}{c}0.0031 \\
(0.00051)\end{array}$ & $1.5 \times 10^{-9}$ & & 194,008 \\
\hline \multirow[t]{2}{*}{$\begin{array}{l}\text { Sex-dim: } \\
\text { men }\end{array}$} & $D G K B, A G M O$ & rs1974619 & 7 & $15,065,300$ & primary & $\mathrm{C} / \mathrm{T}$ & 0.45 & $\begin{array}{c}-0.0037 \\
(0.00038)\end{array}$ & $8.2 \times 10^{-22}$ & $1.2 \times 10^{-5}$ & 233,066 \\
\hline & & & & & & & 0.45 & $\begin{array}{c}-0.0063 \\
(0.00046)\end{array}$ & $1.0 \times 10^{-42}$ & & 194,008 \\
\hline \multirow[t]{2}{*}{$\begin{array}{l}\text { Sex-dim: } \\
\text { women }\end{array}$} & SRRM3 & rs11773850 & 7 & $75,824,961$ & $\begin{array}{c}\text { in LD with } \\
\text { primary }\end{array}$ & $\mathrm{G} / \mathrm{A}$ & 0.98 & $\begin{array}{c}-0.0087 \\
(0.0013)\end{array}$ & $4.2 \times 10^{-11}$ & 0.0014 & 233,066 \\
\hline & & & & & & & 098 & -0.0021 & 018 & & 194008 \\
\hline \multirow[t]{2}{*}{$\begin{array}{l}\text { Sex-dim: } \\
\text { men }\end{array}$} & $P O P 7, E P O$ & rs534043 & 7 & $100,312,724$ & primary & $A / G$ & 0.11 & $\begin{array}{c}-0.0019 \\
(0.00060)\end{array}$ & 0.0014 & 0.0016 & 233,066 \\
\hline & & & & & & & 0.11 & $\begin{array}{c}-0.0048 \\
(0.00072)\end{array}$ & $1.6 \times 10^{-11}$ & & 194,008 \\
\hline \multirow[t]{3}{*}{$\begin{array}{l}\text { Sex-dim: } \\
\text { women }\end{array}$} & R3HDM2 & rs7484541 & 12 & $57,714,803$ & $\begin{array}{l}\text { in LD with } \\
\text { primary }\end{array}$ & $\mathrm{A} / \mathrm{T}$ & 0.78 & $\begin{array}{c}0.0032 \\
(0.00046)\end{array}$ & $5.3 \times 10^{-12}$ & 0.030 & 233,066 \\
\hline & & & & & & & & 0.0016 & & & \\
\hline & & & & & & & 0.78 & $(0.00056)$ & 0.0037 & & 194,008 \\
\hline \multirow[t]{3}{*}{$\begin{array}{l}\text { Sex-dim: } \\
\text { men }\end{array}$} & $R M S T$ & rs6538804 & 12 & $97,848,910$ & primary & $\mathrm{C} / \mathrm{G}$ & 0.60 & $\begin{array}{c}0.0016 \\
(0.00040)\end{array}$ & $7.3 \times 10^{-5}$ & $6.0 \times 10^{-4}$ & 233,066 \\
\hline & & & & & & & & 0.0037 & & & \\
\hline & & & & & & & 0.60 & $(0.00048)$ & $7.8 \times 10^{-15}$ & & 194,008 \\
\hline \multirow[t]{3}{*}{$\begin{array}{l}\text { Sex-dim: } \\
\text { men }\end{array}$} & FBRSL1 & rs11146926 & 12 & $133,125,450$ & primary & $\mathrm{G} / \mathrm{A}$ & 0.78 & $\begin{array}{c}-0.0014 \\
(0.00046)\end{array}$ & 0.0035 & 0.016 & 233,066 \\
\hline & & & & & & & & -0.0031 & & & \\
\hline & & & & & & & 0.78 & $(0.00056)$ & $2.3 \times 10^{-8}$ & & 194,008 \\
\hline \multirow[t]{2}{*}{$\begin{array}{l}\text { Sex-dim: } \\
\text { women }\end{array}$} & FAM234A & rs9929922 & 16 & 294,749 & $\begin{array}{c}\text { in LD with } \\
\text { primary }\end{array}$ & $A / G$ & 0.82 & $\begin{array}{c}0.0042 \\
(0.00049)\end{array}$ & $4.8 \times 10^{-18}$ & 0.033 & 233,066 \\
\hline & & & & & & & 0.82 & $\begin{array}{c}0.0026 \\
(0.00059)\end{array}$ & $9.6 \times 10^{-6}$ & & 194,008 \\
\hline
\end{tabular}


medRxiv preprint doi: https://doi.org/10.1101/2021.04.17.21255471; this version posted April 20, 2021. The copyright holder for this preprint (which was not certified by peer review) is the author/funder, who has granted medRxiv a license to display the preprint in perpetuity.

$12 \overline{75}$

\begin{tabular}{|c|c|c|c|c|c|c|c|c|c|c|c|}
\hline $\begin{array}{l}\text { Sex-dim: } \\
\text { women }\end{array}$ & $S L C 43 A 2$ & rs56405641 & 17 & $1,528,464$ & primary & $\mathrm{C} / \mathrm{T}$ & 0.91 & $\begin{array}{c}-0.004 \\
(0.00067)\end{array}$ & $2.2 \times 10^{-9}$ & $2.7 \times 10^{-4}$ & 233,066 \\
\hline & & & & & & & & -0.00020 & & & \\
\hline & & & & & & & 0.91 & $(0.00080)$ & 0.81 & & 194,008 \\
\hline
\end{tabular}

1276 Chr: chromosome; Pos: Position GRCh37; nonsyn: non-synonymoys; sex-dim: sex-dimorphic;

1277 EAF: allele frequency of the random glucose (RG) raising allele. A signal was annotated as

1278 "European" if it had reached genome-wide significance $\left(P<5 \times 10^{-8}\right)$ in the meta-analysis of

1279 European cohorts in either of our two models of interest with adjustment for age, sex with or

1280 without time since last meal (where available) along with exclusion of extreme

1281 hyperglycaemia ( $R G>20 \mathrm{mmol} / \mathrm{L}$ ) or in their combination. A signal was annotated as

1282 "European, UKBB only" if it had reached genome-wide significance $\left(P<5 \times 10^{-8}\right)$ in UKBB in any

1283 of the six RG models (Methods). The EAF and $P$-values reported here are from the combined

1284 RG model. Heterogeneity among studies was assessed using the $\mathrm{I}^{2}$ index. The Cochran's Q-

1285 test (for sex heterogeneity representing the differences in allelic effects between sexes) $P$ -

1286 value is also shown. Sex-dimorphic effects and $P$-values are presented first for women.

1287

1288

1289

1290

1291

1292

1293

1294

1295

1296 
medRxiv preprint doi: https://doi.org/10.1101/2021.04.17.21255471; this version posted April 20, 2021. The copyright holder for this preprint (which was not certified by peer review) is the author/funder, who has granted medRxiv a license to display the preprint in perpetuity. All rights reserved. No reuse allowed without permission.

1298 Figure 1. Summary of all RG loci identified in this study.

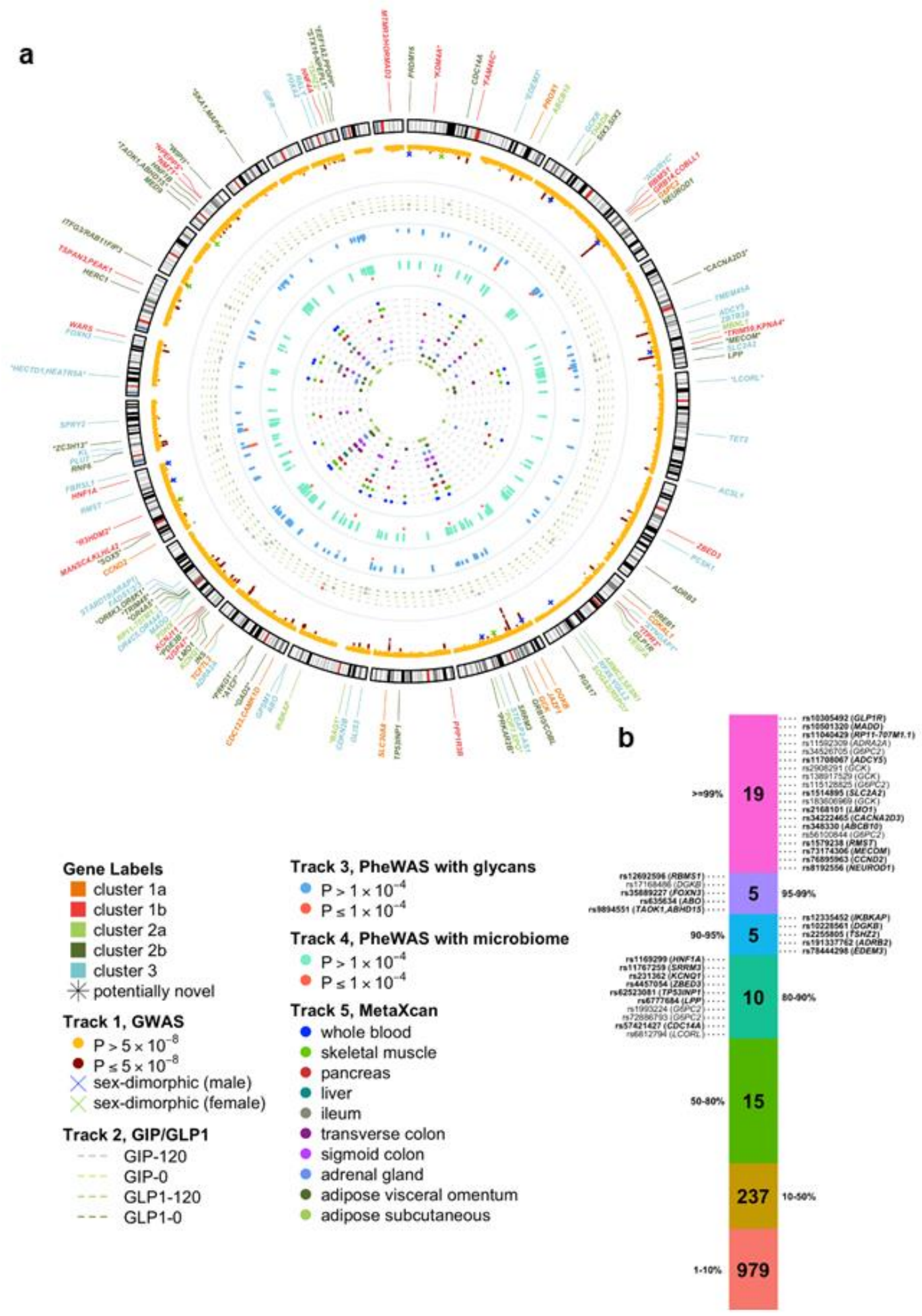


medRxiv preprint doi: https://doi.org/10.1101/2021.04.17.21255471; this version posted April 20, 2021. The copyright holder for this preprint (which was not certified by peer review) is the author/funder, who has granted medRxiv a license to display the preprint in perpetuity. All rights reserved. No reuse allowed without permission.

1300

1301

1302

1303

1304

1305

1306

1307

1308

1309

1310

1311

1312

1313

1314

1315

1316

1317

1318

1319

1320

1321

1322

(a) Circular Manhattan plot summarising findings from the present study. Outermost layer:

Gene names of the 162 distinct RG signals are labelled with different colours indicating three clusters defined in cluster analysis: $1 a / b=$ metabolic syndrome, $2 a / b=$ insulin release versus insulin action (with additional effects on inflammatory bowel disease for cluster 2a), $3=$ defects of insulin secretion (Methods). Asterisks annotate novel for glycaemic traits RG signals. Track 1: RG Manhattan plot reporting -log10( $P$-value) for RG-GWAS meta-analysis, signals reaching genome-wide significance $\left(P\right.$-value $\left.<5 \times 10^{-8}\right)$ are coloured in red. Crosses annotate genome-wide significant loci that show evidence of sex heterogeneity (Methods): blue crosses indicate signals with larger effects in men, green crosses - signals with larger effects in women. Track 2: Effects of RG genome-wide significant on four GIP/GLP-1-related traits GWAS. The colours of the dotted lines indicate four GIP/GLP-1-related traits, grey dot signals reaching $P$-value $<0.01$ for a GIP/GLP-1-related trait, red dot - lead SNP has significant effect on GIP/GLP-1-related trait (Bonferroni-corrected $P$-value $<1 \times 10^{-4}$ ). Track 3: Effects [$\log 10(P$-value)] of lead RG variants in 113 glycan PheWAS. Blue dots - RG lead SNPs, red dots - lead SNPs reaching $P$-value<10-4. Track 4: Effects $[-\log 10(P$-value $)]$ of lead RG variants in 204 gut-microbiome PheWAS. Light green dots - RG lead SNPs, red dots - variants with significant effects at $P$-value $<10^{-4}$. Track 5: MetaXcan results for 10 selected tissues for RG GWAS metaanalysis (Methods), signals colocalising with genes $\left(P\right.$-value $\left.<5 \times 10^{-6}\right)$ are plotted for each tissue. (b) Credible set analysis of RG associations in the European meta-analysis. Variants from each of the RG signal credible sets are grouped based on their posterior probability (the percentiles labelled on the sides of the bar). SNP variants with posterior probability $>80 \%$, along with their locus names are provided. All variants from the credible set of the primary signals are highlighted in bold. 
medRxiv preprint doi: https://doi.org/10.1101/2021.04.17.21255471; this version posted April 20, 2021. The copyright holder for this preprint (which was not certified by peer review) is the author/funder, who has granted medRxiv a license to display the preprint in perpetuity. All rights reserved. No reuse allowed without permission.

Figure 2. Functional and structural analysis of coding GLP1R variants.
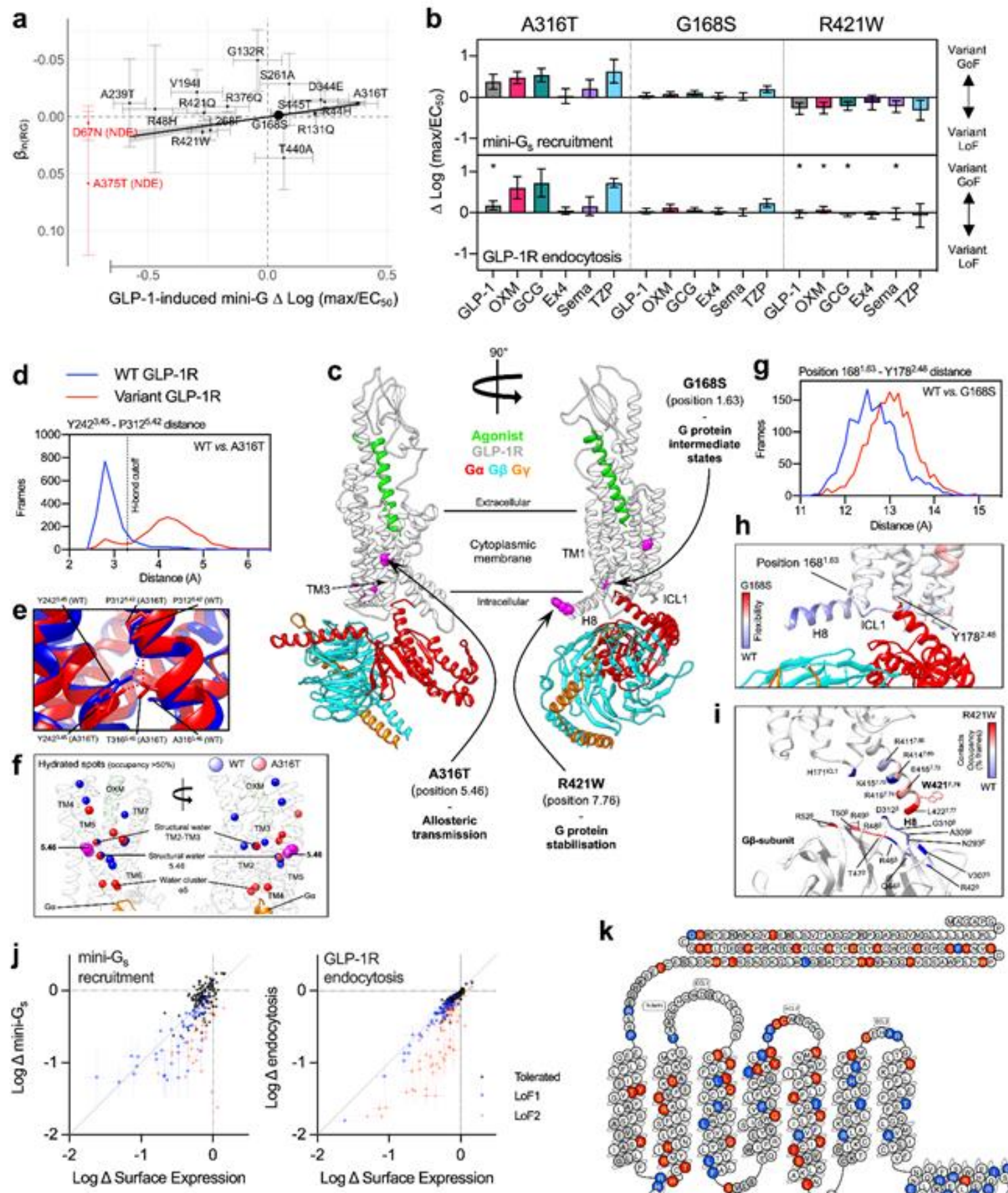

1325

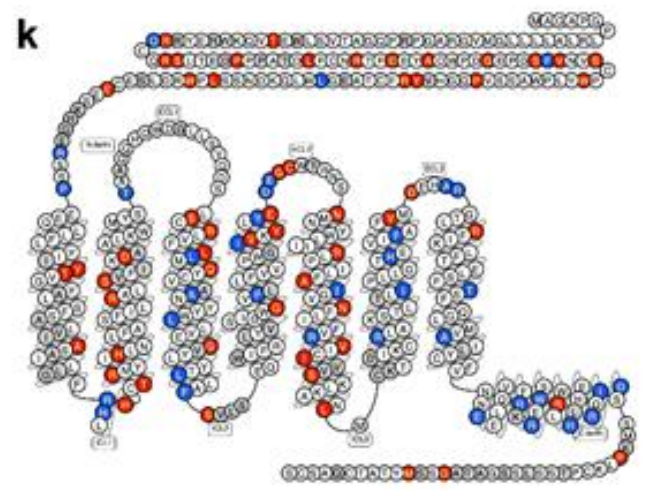

1326 (a) Weighted regression of AST20 $\beta_{R G}$ estimated in the UKBB study on GLP1R variant mini- $\mathrm{G}_{\mathrm{s}}$

1327 response to GLP-1 stimulation, with correction for variant surface expression, $n=5-13$. Size of dots is proportional to the weight (minor allele frequency) in the regression model (Methods).

1329 Error bars represent standard errors for $\beta_{R G}$ and mini- $G_{s}$ coupling in response to GLP-1 
medRxiv preprint doi: https://doi.org/10.1101/2021.04.17.21255471; this version posted April 20, 2021. The copyright holder for this preprint (which was not certified by peer review) is the author/funder, who has granted medRxiv a license to display the preprint in perpetuity. All rights reserved. No reuse allowed without permission.

1330

1331

1332

1333

1334

1335

1336

1337

1338

1339

1340

1341

1342

1343

1344

1345

1346

stimulation. The grey shaded area corresponds to the $95 \%$ confidence interval of the slope of the regression analysis $(\beta=-0.027,95 \% \mathrm{Cl}[-0.036-\{-0.016\}], P$-value $=0.0001)$, which explained $65 \%$ of the variance in these associations. Variants in red showed no detectable surface expression (NDE) and are not included in regression analysis. (b) GLP1R variant mini-Gs coupling and receptor endocytosis, with surface expression correction, in response to GLP-1, oxyntomodulin (OXM), glucagon (GCG), exendin-4 (Ex4), semaglutide (Sema) and tirzepatide (TZP), $n=6$. Positive deviation indicates variant gain-of-function, with statistical significance inferred when the $95 \%$ confidence intervals shown do not cross zero. Responses are also compared between pathways by unpaired t-test, with * indicating statistically significant differences. (c) Architecture of the complex formed between the agonist-bound GLP-1R and Gs; the likely effect triggered by residues involved in GLP-1R isoforms A316T, G168S, and R421W (in magenta) are reported. (d) Distributions of the distance between $\mathrm{Y} 242^{3.45}$ side chain and P312 5.42 backbone computed during MD simulations of GLP-1R WT and A316T; the cut-off distance for hydrogen bond is shown. (e) Difference in the hydrogen bond network between GLP1-R WT and A316T. (f) Analysis of water molecules within the TMD of GLP1-R WT and A316T suggests minor changes in the local hydration of position 5.46 (unperturbed structural water molecule). (g) Distributions of the distance between position $168^{1.63}$ and Y178 2.48 during molecular dynamics simulations of GLP-1R WT and G168S. (h) During MD simulations the GLP-1R isoform S168G showed increased flexibility of ICL1 and H8 compared to WT, suggesting a different influence on $\mathrm{G}$ protein intermediate states. (i) Contact differences between Gs and GLP-1R WT or W421R; the C terminal of W421R H8 made more interactions with $N$ terminal segment of $G s \beta$ subunit. (j) Mini- $G_{s}$ and GLP-1R endocytosis responses to $20 \mathrm{nM}$ exendin-4, plotted against surface GLP-1R expression, from 196 missense GLP1R variants transiently transfected in HEK293T cells ( $n=5$ repeats per assay), with data 
medRxiv preprint doi: https://doi.org/10.1101/2021.04.17.21255471; this version posted April 20, 2021. The copyright holder for this preprint (which was not certified by peer review) is the author/funder, who has granted medRxiv a license to display the preprint in perpetuity.

All rights reserved. No reuse allowed without permission.

represented as mean \pm standard error after normalization to wild-type response and $\log _{10^{-}}$

1355 transformation. Variants are categorised as "LoF1" when the response 95\% confidence

1356 interval falls below zero or "LoF2" where expression-normalised 95\% confidence interval falls

1357 below zero. (k) GLP-1R snake plot created using gpcr.com summarizing the functional impact

1358 of missense variants; for residues with $>1$ variant, classification is applied as

1359 LoF2>LoF1>tolerated.

1360

1361 Figure 3. Deterioration of glucose homeostasis progressing into type 2 diabetes (T2D) and

1362 leading to complications in multiple organs and tissues - established (left, in peach colour)

1363 and new (right, in green).

1364 
medRxiv preprint doi: https://doi.org/10.1101/2021.04.17.21255471; this version posted April 20, 2021. The copyright holder for this preprint (which was not certified by peer review) is the author/funder, who has granted medRxiv a license to display the preprint in perpetuity.

a
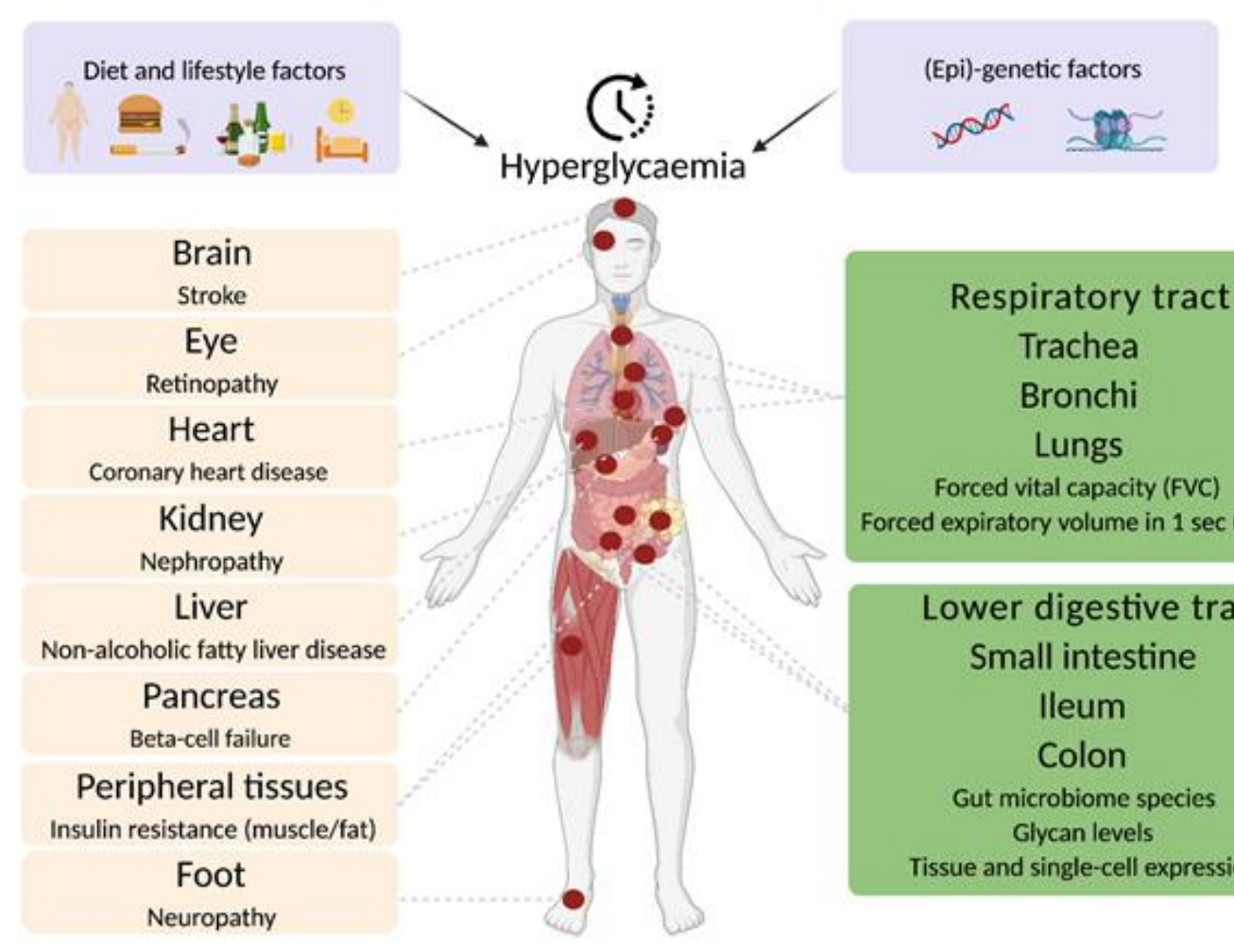

b

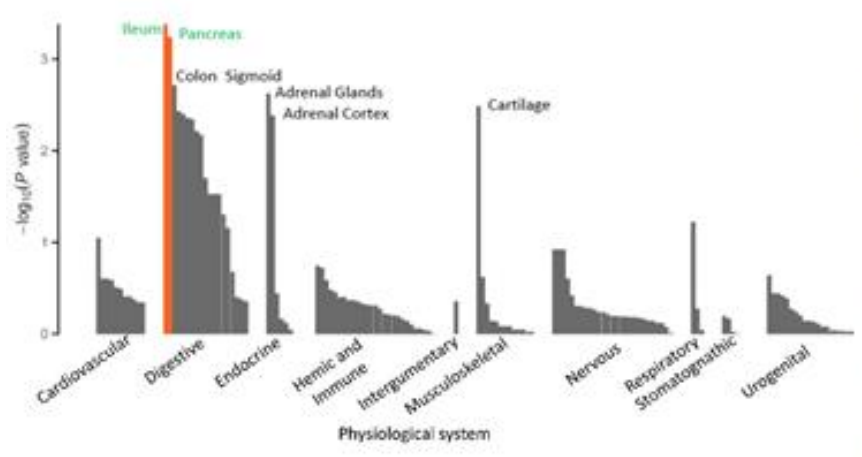

c

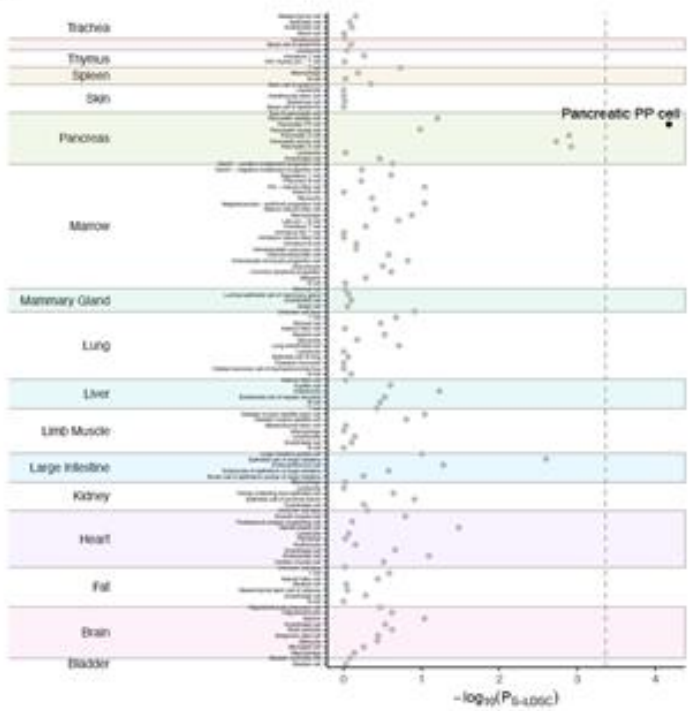

Respiratory tract

Trachea

Bronchi

Lungs

Forced vital capacity (FVC) Forced expiratory volume in $1 \mathrm{sec}$ (FEV1)

\section{Lower digestive tract}

Small intestine

lleum

Colon

Gut microbiome species

Glycan levels

Tissue and single-cell expression

1366 (a) A human figure illustrating the main causes of hyperglycemia (a combination of lifestyle

1367 and genetic factors), and how hyperglycemia affects many organs and tissues. Complications

1368 on the left panel are well established for T2D. Those on the right panel are emerging ones and

1369 are supported by our current analyses. (b) Functional annotation of the RG GWAS results with

1370 DEPICT (Methods). (c) Functional annotation of the RG GWAS results with CELLECT

1371 (Methods). 
medRxiv preprint doi: https://doi.org/10.1101/2021.04.17.21255471; this version posted April 20, 2021. The copyright holder for this preprint (which was not certified by peer review) is the author/funder, who has granted medRxiv a license to display the preprint in perpetuity. All rights reserved. No reuse allowed without permission.

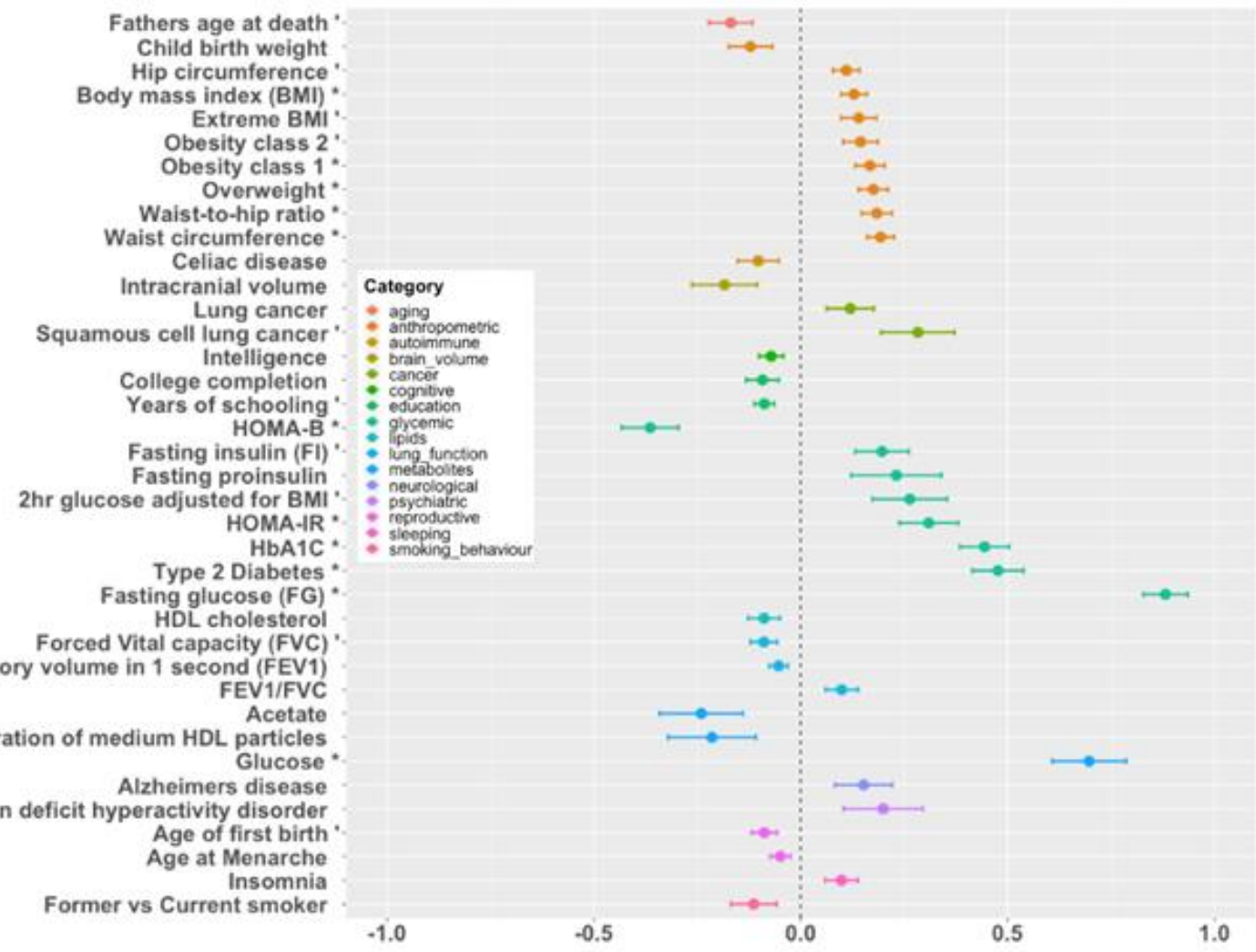

$1374 \mathrm{X}$ axis provides the $\mathrm{r}_{\mathrm{g}}$ genetic correlation values for traits or diseases ( $\mathrm{Y}$ axis) reaching at

1375 least nominal significance. Correlations reaching a $P$-value $<0.01$ are labelled with " ‘ ", and

1376 those $P$-value $<0.05 / 239$ are labelled with " * ". 